\title{
Digitální literární kartografie a kvantifikace segmentů literárně narativního textu - metodologie, nástroje a interpretační strategie (popis jednoho projektu)
} Richard Zmèlík

\author{
ZMĚLÍK, R.: Digital Literary Cartography and Segment-Quantification \\ of Literary Narrative Text - Methodology, Tools and Interpretive \\ Strategies (The Description of one Project) \\ SLOVENSKÁ LITERATÚRA 67, 2020, No. 6, p. 523 - 551 \\ DOI: https://doi.org/10.31577/slovlit.2020.67.6.2 \\ ORCID: 0000-0002-5414-4574
}

Key words: Digital Humanities, Digital Literary Cartography, Digital Literary Studies, quantification of narrative text, data-modelling

The paper deals with chosen DH methods in literary studies, which are focused on modelling of fictional topography and narrative segments quantification. The first part of article presents the methodology concentrated on building of spacial models and their explanation. In the second part are presented the quantitative models of literary-segments such different narrative speeches, character speech, description or so called text in text (letter, diary and so on). Our goal is to present not only the results of this modeling processes, but the way to them. For this purpose the paper presents detailed methodology and procedure associated for example with python coding. In the last part it offers the interpretation strategy growed from comparation between two types of models - spatial and quantitative models. Presented work is only the part of emerging project heading towards on corpus of Czech novels of 19th century.

Klúčové slová: digitálne humanitné vedy, digitálna literárna kartografia, digitálne literárne štúdiá, kvantifikácia literárneho textu, modelovanie dát 


\section{1. Úvodem}

Pojem Digital Humanities $(\mathrm{DH})$ se postupně začíná etablovat také v českém prostředí, jak o tom svědčí dnes již nejeden z projektů českých humanitních vědců, kteří pro svoji práci využívají digitální nástroje. ${ }^{1}$ Nejsou to ale jen dílčí projekty; svoji nezastupitelnou úlohu při propagaci témat a metod spojených s DH mají také veřejné diskuze, at již formou kulatých stolů nebo konferencí, jež přirozeně mají mezioborový charakter. ${ }^{2}$ Tak tomu bylo kupř́kladu i v roce 2019 na pražské konferenci New Media Inspiration: Digital Humanities, kde se potkali badatelé z různých humanitních oborů (literární vědy, lingvistiky, sémiotiky, žurnalistiky, filozofie apod.) prezentující výsledky svého dosavadního bádání, at již se jednalo o analýzu tematicky zaměřených twitterových zpráv, bibliografické databáze, kvantitativní analýzy diskurzu českých médií a jejich proměny nebo modelování témat s ohledem na genderovou př́slušnost autora aj. ${ }^{3}$

V následujícím textu bych rád věnoval pozornost tomu, co lze zařadit do oblasti Digital Humanities v literární vědě (Digital Literary Studies) či do oblasti komputační literární vědy (Computational Literary Studies) ${ }^{4}$ Půjde o dvě základní témata, z nichž první bude věnováno literární kartografii, druhé kvantifikaci narativních, jakož i nenarativních promluvových, deskriptivních a dalších segmentů v umělecké fikci.

Soustředím se výhradně na problematiku spojenou s narativními uměleckými texty; výzkum poezie je u nás zastoupen projektem Korpus českého verše (viz pozn. 4) a badatelskými výsledky jeho autora Petra Plecháče. Oblasti výzkumu fikčních narativů z pohledu Digital Humanities se prozatím v českém literárněvědném prostředí nevěnuje žádná pozornost. Mým cílem v tuto chvíli není tento prostor zaplnit, ale předložit k úvaze jednu z možných cest, která vyplývá z aktuálního výzkumného záměru, jehož dílčí, respektive první vzorové výsledky jsou v tomto textu prezentovány. Úmyslem tedy není předkládat hotová řešení, což v tuto chvíli ani není možné, ale na základě prezentované problematiky nechat jednak nahlédnout do oblasti metodologie, jednak iniciovat př́padnou kritickou diskuzi nad takto orientovaným přístupem.

1 Za všechny jmenujme např́klad Josefa Šlerku, vedoucího oboru Studia nových médií na Fakultě humanitních studií Univerzity Karlovy, který se soustředí na diskurzivní analýzu médií za pomocí statistických nástrojů využívajících digitální platformu.

2 Vůbec poprvé se o DH v kontextu české literární vědy začalo veřejně hovořit v roce 2017, kdy na Ústavu pro českou literaturu AV ČR proběhlo diskuzní setkání pod názvem Digital Humanities a literární věda. Účastníky byli: Richard Změlík, Karel Piorecký, Petr Plecháč, Milan Tvrdík, Michael Wögerbauer, Silvie Cinková, moderoval Josef Šlerka. Záznam z diskuze je dostupný na: https://vimeo.com/244618425.

3 Program je dostupný zde: https://uisk.ff.cuni.cz/wp-content/uploads/sites/62/2019/10/NMI program19.pdf.

4 V českém literárněvědném prostředí vzniklo jen pár takto orientovaných prací, s výjimkou dvou monografií autora tohoto textu, jimiž jsou Kvantivně-korpusová analýza a literární věda (2015) a Konceptualizace barev v narativni fikci na pozadí kvantitativnich modeli̊ (2019), to je společná monografie Petra Plecháče a Roberta Kolára Kapitoly z korpusové versologie (2017), jež vychází z projektu Korpusu českého verše (dostupné na: http://versologie.cz/v2/web_content/corpus.php?lang=cz). Zvyšující se zájem o DH $\mathrm{v}$ českém literárněvědném prostředí dokládá i jedno z témat plánovaného světového bohemistického kongresu v Praze (dostupné na: https://www.6kongres.info/), který byl z důvodu celosvětové pandemie COVID-19 přesunut na rok 2021. 
Nebudu zde zabíhat do obecně teoretické oblasti dané problematiky, ${ }^{5}$ která zejména v zahraničním výzkumu disponuje řadou jak teoretických, tak praktických výsledků; za všechny jmenujme alespoň pár nejnovějších, např. kolektivní práci Davida Coopera, Christophera Donaldsona a Patricie Murriety-Flores nazvanou Literary Mapping in the Digital Age (2016) či kolektivní monografii Literature and Cartography: Theories, Histories, Genres (2017). Zcela jistě zde nelze opomenout jeden ze zakladatelských počinů takto orientovaného výzkumu, kterým je publikace Franca Morettiho Atlas of the European Novel, 1800 - 1900 (1999) nebo projekt švýcarské badatelsky Barbary Piatti A Literary Atlas of Europe, který je realizován od roku 2006. Dnes je samozřejmě $\mathrm{k}$ dispozici řada digitálních literárních atlasů různého typu, jakým je kupř́kladu i Cartographic Imaginaries: Interpreting Literary Atlas, který má s předchozím projektem společné to, že se pokouší přenést události z fikčních světů do kartografického podkladu pomocí tzv. GIS (geografického informačního systému). ${ }^{6}$

V tomto př́spěvku budu mapovat, respektive prostorově modelovat fikční topografii Prahy, a to v prvních pěti romanetech Jakuba Arbesa. ${ }^{7}$ Nespornou výhodou takové volby je skutečnost, že Arbes (a zdaleka nejen on) ve svých prózách významně tematizuje Prahu druhé poloviny 19. století, přičemž často využívá pražská toponyma spolu s mnohdy detailními popisy míst a trajektoriemi postav. Jeden z problémů takovéto projekce však může nastat $v$ př́padě inkoherence mezi mapovým podkladem a fikčním světem. Ve výše uvedených projektech se fikční topografie většinou promítá do aktuálního mapového základu, což ovšem může vyvolávat řadu otázek spojených zejména s potřebou modelování dnes již zaniklých či přepsaných lokalit. Samozřejmě je možné taková místa do aktuálního mapového podkladu zanést jednoduše tak, že jsou nahrazena současnou lokalitou a jejím názvem. Uvedený postup jisté řešení nabízí; je vhodný zejména pro takové projekty, které hodlají přenášet literární místa a dějiště do aktuálních map, a „nasytit“ tak skutečná místa literární topografií. Ačkoli takové přístupy mohou být zajímavé z hlediska marketingu a propagace reálných lokalit, pro literární vědu mají spíše sekundární význam, nebot'jsou výsledkem nivelizace fikční topografie na rovinu reálné topografie, a navíc - jak tomu může být u časově vzdálenějších literárních děl-s mnohdy významnou topografickou inkoherencí mezi tematizovaným historickým prostředím a dnešní situací. Lze jistě oprávněně namítat, že

5 Kromě přirozeného čtenářského sklonu projektovat si literární místa at již do konkrétních reálií anebo do imaginárních map k tomu speciálně vytvořených, lze zájem o prostorovou problematiku (nejen) v literární vědě sledovat zejména od osmdesátých let 20. století v souvislosti s tzv. obratem k prostoru (spatial turn), jak o něm hovoři Doris Bachmann-Medick v monografii Cultural Turns: Neuorientierungen in den Kulturwissenschaften (2007).

6 V prípadě projektu A Literary Atlas of Europe je konkrétní metodologie představena v článku Modelling Uncertain Geodata for the Literary Atlas of Europe (2013)

(dostupné na: http://www.literaturatlas.eu/en/2013/01/16/datenmodellierung-unpraziser-geodaten-fur-den-literarischen-atlas-europas/index.html).

7 Jedná se o prózy: Ďábel na skripci (1865), Elegie o černých očích (1865), Svatý Xaverius (1873), Sivooký démon (1873) a Zázračná madona (1875). 
526 ani dílu z minulého století nemusí být adekvátní dobový mapový podklad. $\mathrm{V}$ takovém př́padě, kdy neexistuje dostatečné množství konkrétních opěrných bodů (toponyma, lokalizace nemající povahu toponym, trajektorie cest apod.), jimiž by bylo možné fixovat místa ve fikčním světě a tato promítat do dobového kartografického modelu, je zbytečné o takovém postupu uvažovat. ${ }^{8}$ To je ostatně i př́pad Arbesova romaneta Elegie o černých očích, pro které nesestavuji prostorový model fikční topografie. Je třeba vždy pamatovat na to, že za každou cenu nelze konfigurovat prostorové modely fikčních topografií, jakkoli se to může jevit lákavé.

Abych předešel inkoherenci mezi fikční topografií a dobovou kartografickou situací, zvolil jsem za výchozí mapový podklad, do kterého je promítána fikční topografie Arbesových próz, mapu Prahy z roku 1873 od Karla Kořistky. ${ }^{9}$ Zde je potřeba blíže vysvětlit důvody, které vedly k takovému postupu. Především není mým cílem dohledání literárních míst v reálné a aktuálně platné mapě Prahy, nebot' prostorové modely, ke kterým ve svém výzkumu směřuji, mají sloužit k systematické analýze fikční topografie a svým způsobem i fikčního prostoru, jakkoli nelze tuto problematiku omezit výhradně na otázku fikční topografie, jak dále ukážu. Současně je třeba upozornit na jednu důležitou okolnost; fikční lokace, které jsou přenášeny do dobového mapového podkladu, nejsou zanášeny tak, jak je to běžné v kartografii, tzn. s ohledem na jejich přesné souřadnice. Jak bylo řečeno, cílem není určit totožnost reálného (či historicky reálného) místa s fikční lokací, ale vytvořit takový obecný prostorový model, který by na základě topograficky přibližné aproximace mohl sloužit k analýze povahy a proměny fikčních topografií. To platí jak pro lokace dějišt', tak pro trajektorie pohybu postav, které mohou být detailně popsány, ale také značně redukovány na informaci o přemístění postavy z bodu A do bodu B. Z hlediska prostorových modelů nemá smysl jejich cesty rekonstruovat ani na základě dobové mapy, nebot' je třeba mít vždy na mysli, že je modelována fikční, nikoli skutečná topografie. Druhý důvod pro volbu historických map je ten, že je možné porovnávat prostorový model fikční topografie s historickou mapou a vyvozovat $\mathrm{z}$ toho př́islušné interpretační konsekvence, které u aktuálního mapového základu nemusí být zřejmé. S tím souvisí další možnosti komparace, které ovšem vyplynou teprve ve chvíli, až bude k dispozici rozsáhlejší databáze textů a prostorových modelů vztahujících se k širšímu časovému rámci, např́íklad ke druhé polovině 19. století. Od takové

8 Jako př́klad lze uvést některé prózy Vítězslava Hálka, ve kterých je dějištěm př́běhů fikční Praha. Přesto je pro ně obtížné sestavit prostorové modely, nebot' se zde až na výjimky neobjevují toponyma, která by nám pomohla takové modely sestavit. To samozřejmě ještě neznamená, že prostorové modely (nikoli již nutně kartografické) nemohou být i v takovémto př́ipadě aplikovány, jak ukázal např. Franco Moretti v kapitole své knihy Grafy, mapy, stromy: Abstraktni modely literární historie (2014), ve které se věnuje literárnímu mapování.

9 Její úplný název zní Plán královského hlavního města Prahy s vůkolím 1873. 
databáze lze očekávat, že umožní nejen srovnání modelů mezi sebou, ale i jejich

četné komparace s reálnými proměnami historické topografie místa. ${ }^{10}$

Nyní přistoupím ke konkrétním prostorovým modelům, které se vztahují

ke čtyřem Arbesovým romanetům. Digitální podoba mapy vznikla překreslením historické mapy do vektorového formátu. ${ }^{11}$ Následně jsem do takového základu zanášel lokace (toponyma), která se v prózách objevují spolu s vyznačením cest, jimiž postava procházela. S ohledem na analyzovaný materiál se jevilo nezbytné jednotlivé lokace odlišit podle toho, zda jsou či nejsou dějištěm událostí a zda se jedná o fikčně reálná místa anebo kupříkladu o místa snová. Na obrázcích 1-4 jsou představeny prostorové modely jednotlivých Arbesových romanet, obrázek 5 je modelem průniku všech dílčích prostorových modelů. Jeho smyslem je vymezit celkový rozsah pražské fikční topografie v analyzovaných prózách.

10 V tomto ohledu je mým cílem vybudovat digitální korpus próz významně tematizujících pražskou topografii. Kromě Arbesova díla budou jeho součástí prózy Jana Nerudy, Karoliny Světlé, Aloise Jiráska, Zikmunda Wintera, Gustava Meyrinka či Franze Kafky apod. (Do budoucna se počíá i s texty z 20. století, což se týká např́klad vybraných próz Daniely Hodrové, Miloše Urbana nebo Michala Ajvaze ad.) Smyslem takového projektu je pomocí prostorových modelů literární kartografie (viz obr. 1 - 5) zmapovat pražskou fikční topografii za účelem celé řady komparací mezi takovými modely, jež napomohou ozřejmit vývojové procesy a vztahy mezi texty, autory a historickými fázemi. Součástí korpusu budou speciálně anotované texty s ohledem na kvantitativní analýzu textových segmentů (viz zde kap. 3). Konečným cílem projektu je ovšem vytvořit obsáhlejší korpus české prózy, který by disponoval také dalšími nástroji analýzy, v prvé řadě tematickou analýzou a stylometrií, která by na základě konkrétně definovaných textových kritérií byla schopna vyhodnotit míru podobnosti mezi texty. Takový výzkum by mohl odhalit zajímavé vazby mezi literárními texty a autory, které by následně mohly být individuálně interpretovány. $Z$ povahy digitálního korpusu pak vyplývají i další možnosti, jež se mohou postupně stát jeho funkcionálními komponentami. Tak počítám rovněž s vytvořením paralelní korpusové databáze (kritických) reflexí literárních textů (recenzí, polemik, odborných prací, oznámení o vydání apod.), jež by s korpusem literárních textů byla funkčně provázána. To pochopitelně předpokládá zvláštní anotaci takových (meta)textů, která by umožnila kvantitativní modelování podle zvolených kritérií (autor, médium, typ textu apod.). Výsledným produktem takovéto databáze by mohly být modely recepčních vln. S takovým manuálně sestaveným modelem pracoval nap̌r. Dalibor Tureček v knize České literární romantično: synopticko-pulzační model kulturního jevu (2012). V souvislosti s celým projektem vznikne rovněž databáze nakladatelství a vydavatelství, jež opět umožní kvantitativní modelování činnosti těchto institucí navzájem a v daném čase. Z praktického hlediska je celý projekt limitován pracovní kapacitou, vysokoškolští studenti v rámci speciálních výběrových seminářo̊ provádějí OCR konkrétních textů a jejich čištění. Při natolik rozsáhlém projektu a minimu personálního potenciálu (s výjimkou př́pravné fáze OCR) je nezbytné při budování takového korpusu postupovat od jeho dílčích oblastí (próza 19. století tematizující Prahu) a segmentů (literárně kartografické modely a kvantitativní modely textových segmentů) $\mathrm{k}$ dalším vrstvám, jež budou představovat jednak nové narativní texty, paratexty, jednak další funkce spojené s možnostmi modelování, jež jsem naznačil výše. (Projekt je postupně realizován zde: http://korpusprozy.cz/.)

11 V této fázi projektu jsou překresleny zejména ty části, jež s analyzovaným materiálem souvisí. 


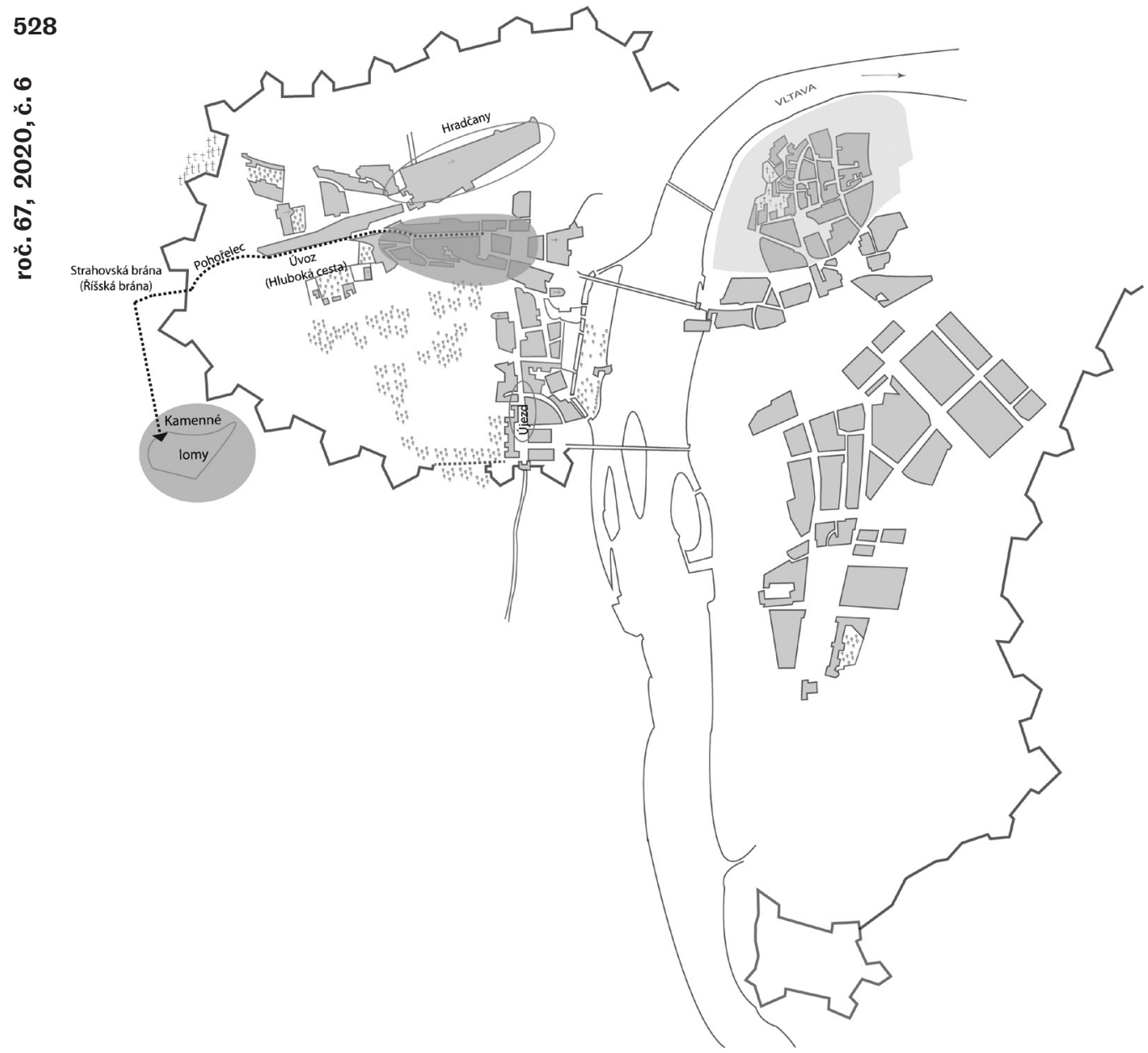

Vysvětlivky:

dějiště, konkrétní místo

širši topografický rámec

misto jmenované např. vypravěčem,

postavou nebo $z$ doslechu, $z$ vyprávění, z mapy,

z hlediska hlavního děje se nejedná o centrální lokace

snové místo, paralelní místo

cesta

zahrady

Josefov

hřbitov 


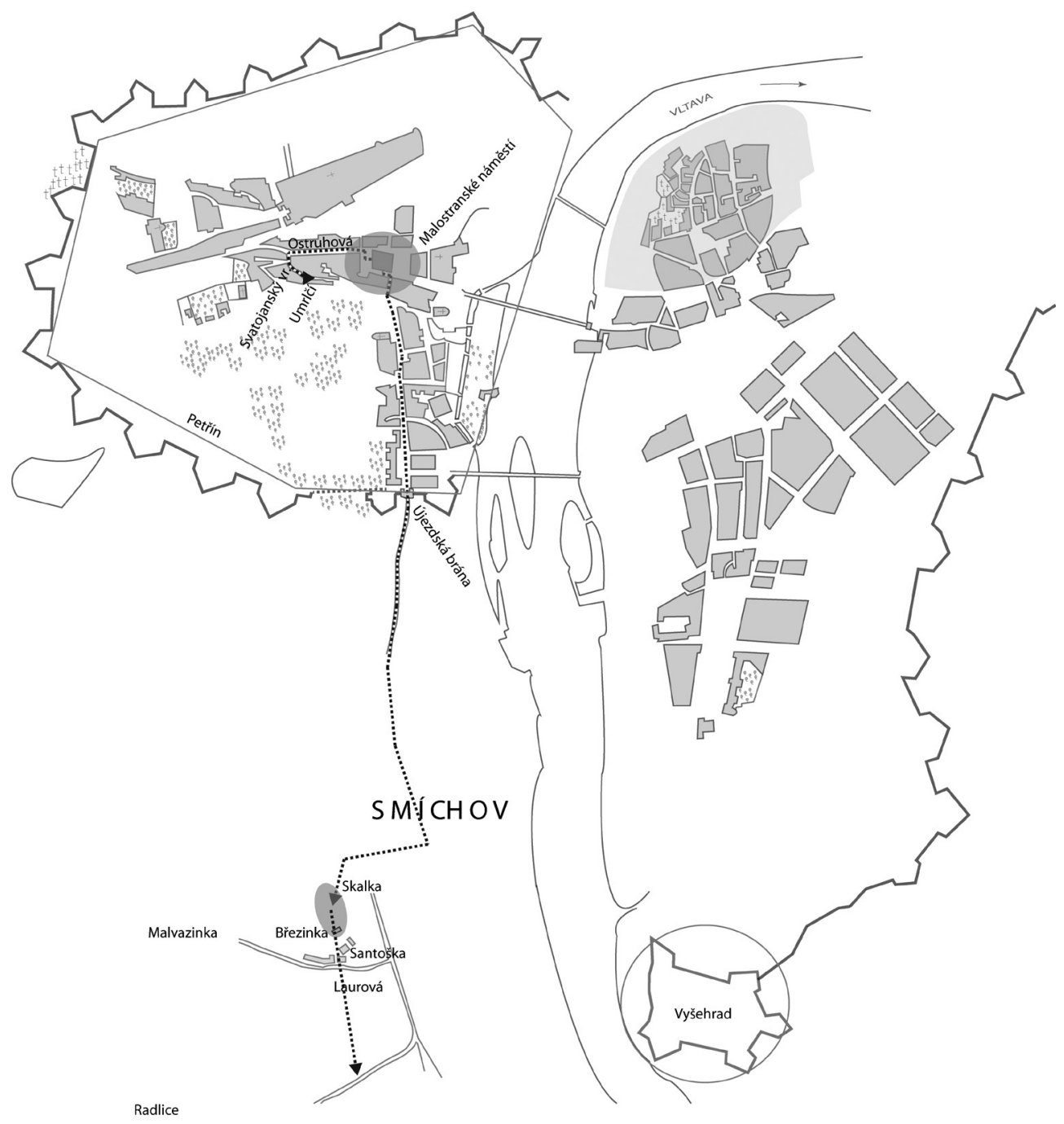

\section{Vysvětlivky:}

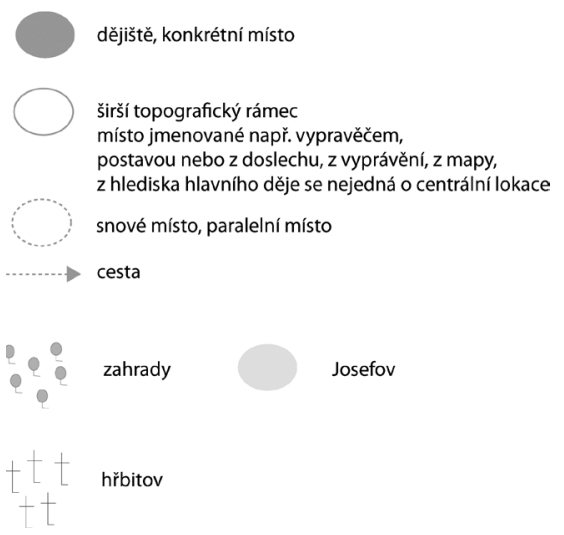




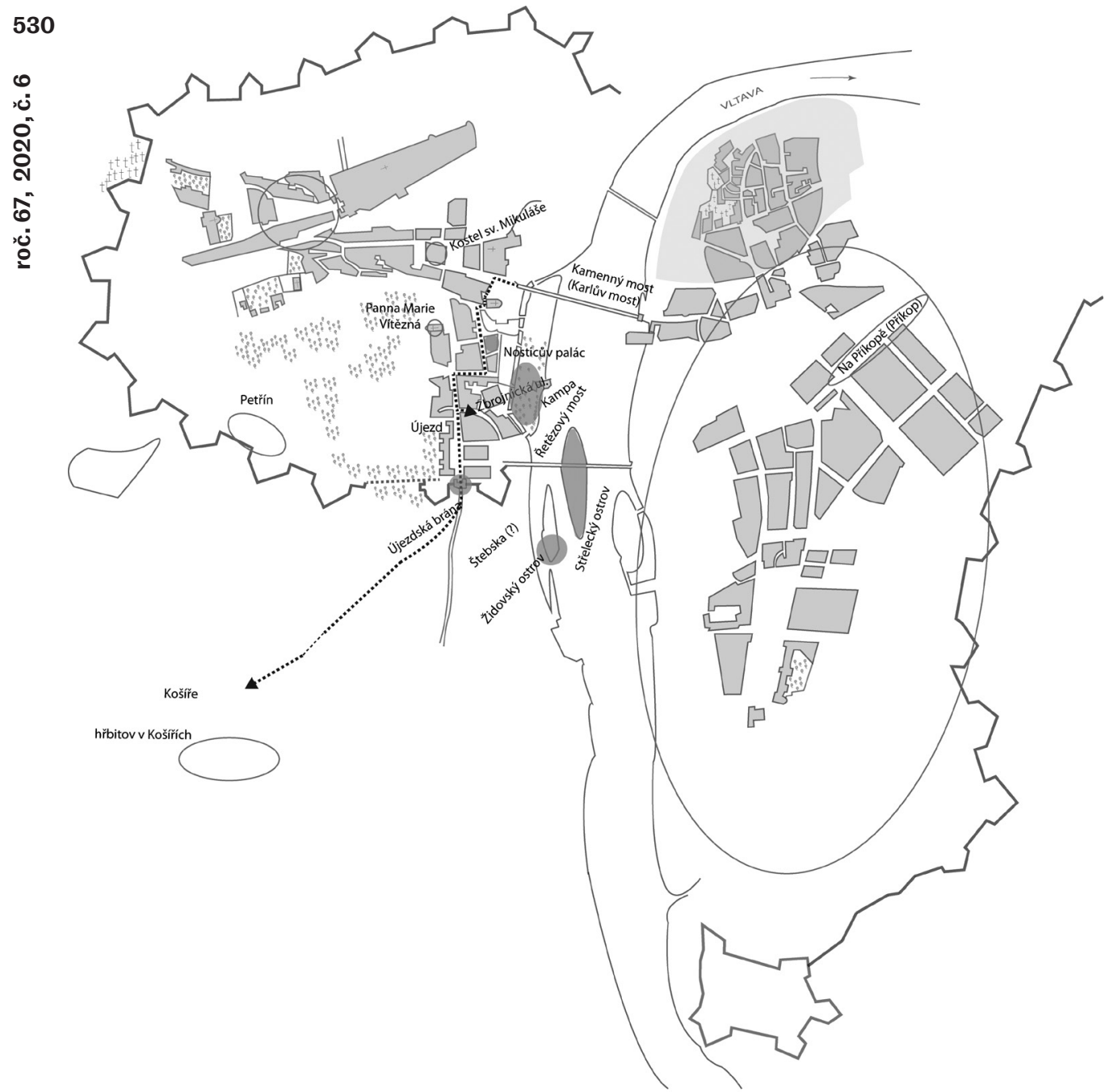

Vysvětlivky:

dějiště, konkrétní misto

Širšl topografický rámec

misto jmenované např. vypravěčem

postavou nebo $z$ doslechu, z vyprávěni, z mapy,

z hlediska hlavního děje se nejedná o centrální lokace

snové misto, paralelní místo

cesta

$2 \%$ zahrady

Josefov

hřbitov

Obr. 3: Prostorový model romaneta Sivooký démon 


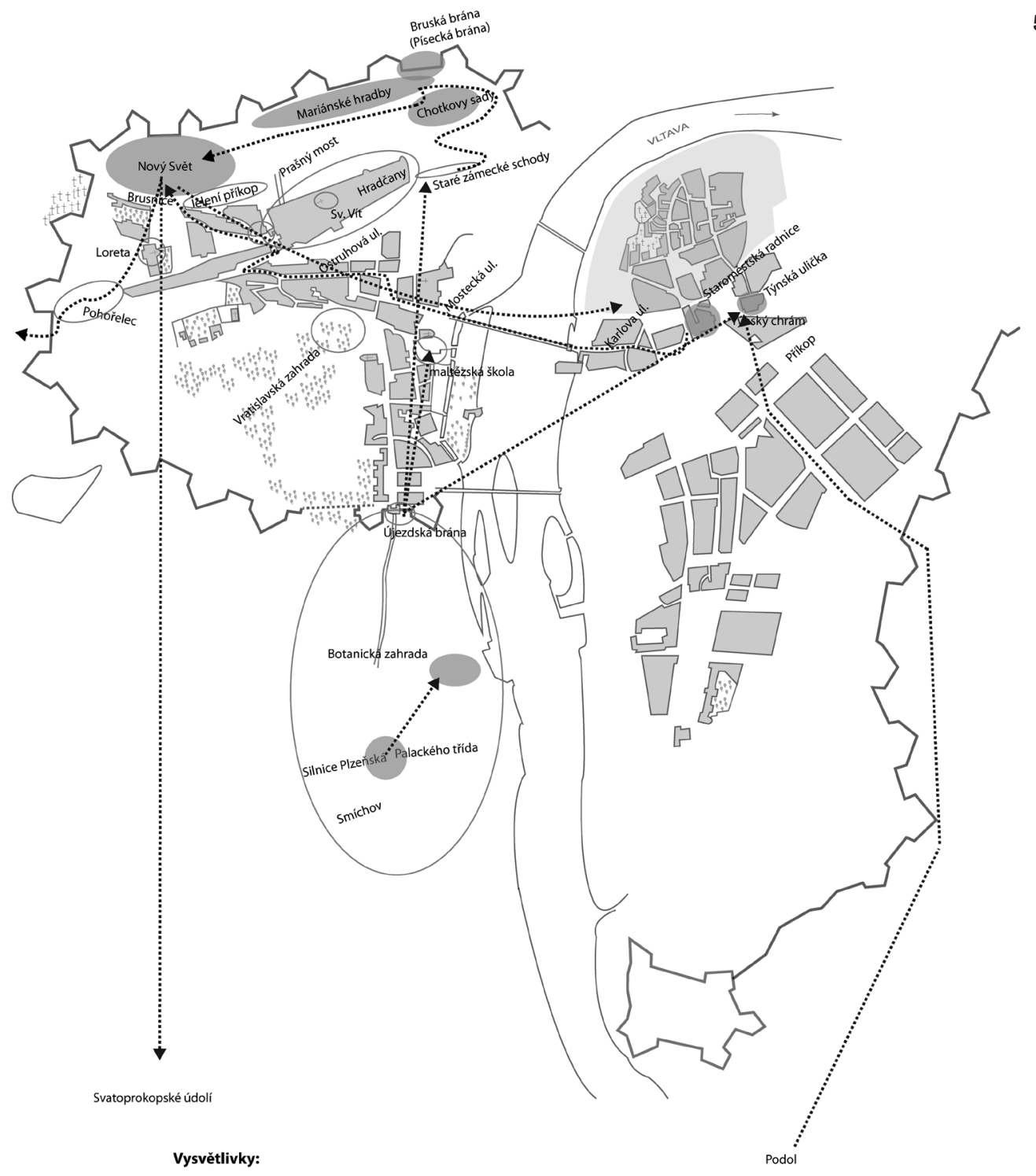

dějiště, konkrétní místo

širši topografický rámec

místo jmenované např. vypravěčem,

postavou nebo z doslechu, z vyprávění, z mapy,

z hlediska hlavního dĕje se nejedná o centrální lokace

snové místo, paralelní místo

cesta

2 zahrady

Josefov

hřhitov 


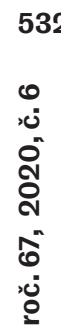

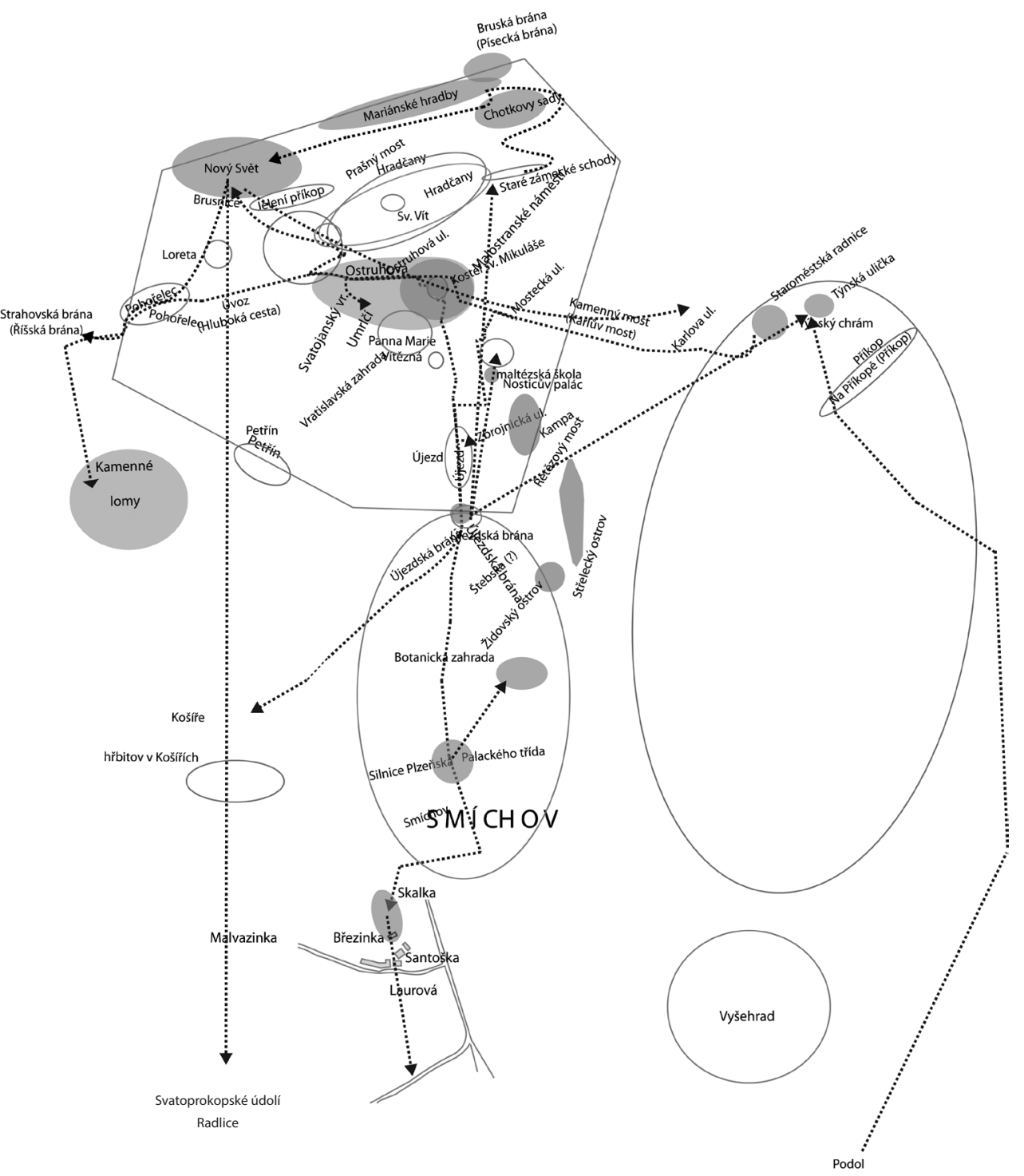

Obr. 5: Prostorový model prvních pěti, respektive čtyř Arbesových romanet 


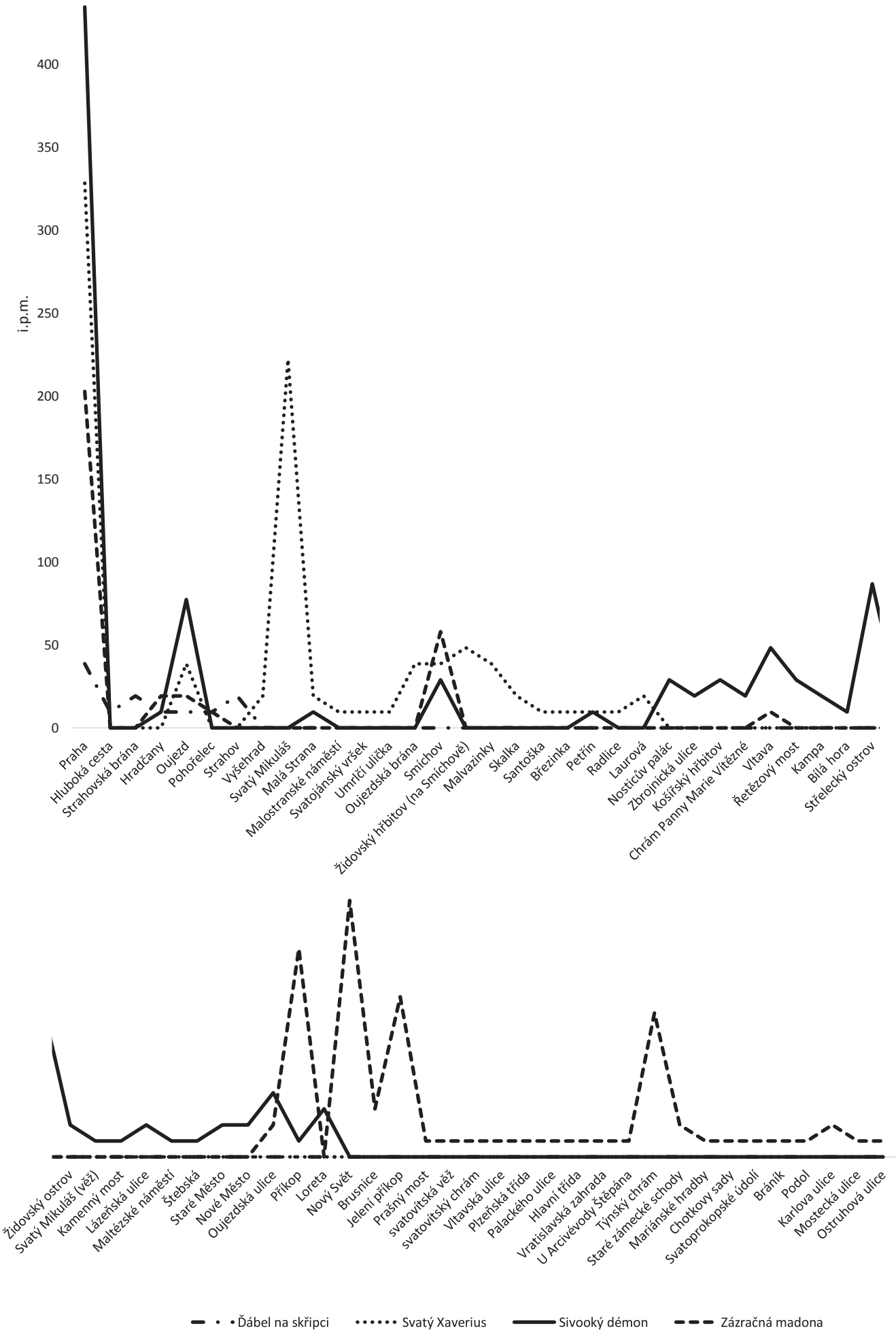




\section{3. Kvantifikace segmentů fikčního narativu}

Segmenty fikčního narativu mám na mysli takové části, jakými jsou narativní promluvy, včetně různých rovin vložených vyprávění, promluvy postav, deskripce nebo tzv. text v textu, jak označujeme dopis nebo deník ve fikčním světě, které lze rovněž relativně samostatně analyzovat. Plošná a plně automatická textová analýza, jež by akceptovala uvedené segmenty fikčních narativů, je značně problematická, ne-li dokonce nemožná. To, co je dnes relativně dobře možné v př́padě poezie, tj. automatická detekce a analýza segmentů verše (metrum, rým, eufonie), se v případě prózy jeví jako značně komplikovaná záležitost. Důvodem je především to, že na rozdíl od poezie postrádáme v př́padě automatické analýzy kupříkladu naratologicky relevantních segmentů oporu pro jejich rigidní formální klasifikaci. Tak jako lze formálně specifikovat metrum nebo rým, není možné univerzálně rozlišit typy narativních promluv, jakými jsou jednotlivé typy vypravěčů. Totéž platí pro různá pásma řeči postav typu př́mé či polopřímé řeči nebo pro takové textové typy, jakými je deskripce. ${ }^{12} \mathrm{~V}$ uvedených prípadech totiž nelze pro konkrétní textový typ nebo narativní promluvu uvažovat společné kritérium, které by platilo ve smyslu stabilního formálního paradigmatu - jako je tomu v poezii-, jež by bylo možné detekovat na povrchové úrovni textu. Právě disproporce mezi povrchovou úrovní částí narativu a jejich funkčním vymezením ${ }^{13}$ znesnadňuje jednoznačnou strojovou delimitaci takových segmentů (podrobněji v části Kazuistika). ${ }^{14}$

Proto je nezbytné, aby taková segmentace probíhala manuálně, a nikoli a priori např́íklad na základě podílu dynamičnosti či statičnosti textu, kterou by bylo možné kvantifikovat způsobem, jaký představili autoři publikace Metody kvantitativníanalýzy (nejen) básnických textů (2014). ${ }^{15} \mathrm{Je}$ třeba říci, že autoři neměli na mysli deskriptivitu ve smyslu literárněvědném, tj. právě jako onen textový typ, jenž je jako deskriptivní definován svojí funkční pozicí v narativním textu, ale aspekt lingvistický vycházející právě toliko z poměru mezi autosémantiky s př́znakem dynamičnosti a lexikem, které neobsahuje významový komponent dějovosti.

Z literárněvědného hlediska je ovšem situace přece jen o něco složitější. Deskripce jako textový typ či segment díla může být vyjádřena narativními

12 K této problematice viz CHATMAN, Seymour: Dohodnuté terminy: rétorika narativu ve fikci a filmu. Přel. Brigita a Luboš Ptáčkovi. Olomouc: Univerzita Palackého, 2000, s. 29 - 43.

13 Abych lépe ozřejmil, co pojmy povrchová a hloubková rovina narativu rozumím, odkážu k dnes již klasické naratologické práci S. Chatmana Dohodnuté termíny: rétorika narativu ve fikci a filmu (2000), vjejímž úvodu jsou pojednány základní textové typy (narativ, deskripce a argument) a jejich funkční vztahy. Pro každý z těchto typů Chatman specifikuje jejich vlastní formální kritéria, jimiž se obecně projevují. Na druhé straně názorně dokládá, jak může být jeden typ funkčně subsumován pod jiný.

14 Jeden ze současných směrů v naratologii se rovněž soustředí na možnosti kvantifikace za účelem exaktního vyjádření některých základních aspektů a oblastí souvisejících s uměleckým narativem. Vyacheslav Yevseyev ve studii Measuring Narrativity in Literary Texts (2005) odpovídá na otázku, jakým způsobem by bylo možné kvantitativně vyjádřit míru narativity textu. David Herman se zase ve studii Quantitative Methods in Narratology: A Corpus-Based Study of Motion Events in Stories (2005) pokusil pomocí kvantifikace sloves pohybu analyzovat prostorové relace v narativu.

15 V kapitole věnované měření tzv. aktivity a deskriptivity textu autoři zavádí vzorec pro jejich výpočet, který definují následovně: „,Metoda měření aktivity a deskriptivity textu je velmi jednoduchá. Vyjdeme-li z předpokladu, že deskriptivita je v textu reprezentována množinou slov $A$ obsahující adjektiva, adverbia, kterými se odpovídá na otázku ,jak?', a nominalizovaná adjektiva, zatímco aktivita je reprezentovaná množinou slov $V$ obsahující verba (kromě být, mít a modálních sloves moci, smět, muset) a deverbativní substantiva, pak celkovou aktivitu textu $Q$ definujeme $Q=\frac{\mathrm{V}}{(\mathrm{V}+\mathrm{A})} . “$ 
sekvencemi a naopak, jak na to upozornil S. Chatman. Rovněž nelze plně auto- 535 maticky postihnout rozdíly mezi jednotlivými vypravěči, jakými jsou vypravěči rétoričtí, ${ }^{16}$ heterodiegetičtí, homodiegetičtí, intradiegetičtí a jejich možné kombinace. ${ }^{17}$ Proto je třeba ve výsledku nejen narativní a deskriptivní části textu delimitovat ručně, což de facto znamená provést jejich interpretaci, která sama o sobě může být komplikovaná i problematická (viz Kazuistika). Toto je jedno z největších úskalí kvantifikace takových segmentů. S tímto problémem se lze vyrovnat jedině odkazem ke koherentní interpretační strategii vycházející z konkrétního teoretického základu, který zajištuje relativně jednotný interpretační princip a jehož parametry jsou aplikovány na všechny analyzované texty. Zdá se, že se tím na druhé straně oslabuje samotná metoda kvantifikace, která v celém analytickém procesu postrádá výsostně dominantní postavení. To je pouze částečná pravda. Jestliže je na jednu stranu obtížné plně automatizovat segmentaci narativních, promluvových či deskriptivních segmentů v textu, neznamená to, že jejich kvantitativní modely ve výsledku ztrácí informační hodnotu. ${ }^{18}$ Míra zastoupení jednotlivých textových typů a zejména možnost sledovat, jak se jejich stratifikace na základě kvantitativního př́znaku proměňuje, náleží k hlavním přednostem takového postupu (který je možné označit za aposteriorní), nehledě na další možnosti komparování těchto modelů s kvalitativně jinými modely, které v našem př́ipadě představují modely fikčních topografií (viz kap. 4).

Přejdu nyní ke konkrétním př́kladům a postupům, kterými jsem dospěl k příslušným kvantitativním modelům textových segmentů. Začnu př́kladem, na kterém ukážu, jak komplikované situace nastávajív konkrétních literárních textech.

\section{Kazuistika: Zázračná madona}

Úvodní část Arbesova romaneta Zázračná madona (1875) je tvořena hned několika překrývajícími se textovými segmenty. První věta je projevem rétorického vypravěče („První dech jara!“), ${ }^{19}$ který svojí řečovou aktivitou (zvoláním) signalizuje svůj vztah k fikčnímu světu či jeho částem; svým způsobem je to komentář ke stavu fikčního světa. Stejně tak je tomu o pár odstavců níže, kde vypravěč vyjadřuje vlastní stanovisko k jedné z pražských částí zvané Nový Svět: „Zvláštní, podivné to zákoutí Prahy!"2o Opět se jedná o zaujetí určitého blíže nespecifikovaného názorového stanoviska vypravěčem. Kromě toho za těmito výpověd'mi následují deskriptivní segmenty, jimiž je evokována atmosféra jarní Prahy, stejně jako popisována obskurní periferie Nového Světa. Postupně však signály rétorického vypravěče zcela mizí a na jeho místo nastupuje „,neosobni“ heterodiegetický vypravěč. Samozřejmě zde vzniká jiná otázka, zda se vlastně stále nejedná o rétorického vypravěče, který pouze proměnil svůj narativní způsob tím, že ve svém promluvovém partu omezil, respektive zcela eliminoval ty složky, jež odkazují k jeho rétorické aktivitě. Na druhé straně v celé další části textu, ve které

16 Viz DOLEŽEL, Lubomír: Narativní zpưsoby v české literatuře. Př́bram : Pistorius \& Olšanská, 2014.

17 Viz RIMMON-KENANOVÁ, Shlomith: Poetika vyprávění. Přel. Vanda Pickettová. Brno: Host, 2001, s. $101-112$.

18 V tuto chvíli se dotýkáme problematiky apriorního a aposteriorního modelování, kterému zde ovšem není věnována detailnější pozornost.

19 ARBES, Jakub: Romaneta. Praha : Nakladatelství Lidové noviny, 2006, s. 149.

20 Tamtéž. 
536 se projevuje heterodiegetický vypravěč, nedochází v narativní promluvě k uplatnění takových znaků, které by signalizovaly jiný typ vypravěče, než je právě heterodiegetický. Celá situace se ovšem zkomplikuje ve chvíli, kdy se dovídáme, že to, co jsme až doposud četli a co nám vyprávěl vypravěč s převládajícími heterodiegetickými znaky, je vlastně vloženým textem (textem v textu), ke kterému se hlásí rétorický vypravěč $v$ ich-formě, jak lze vysledovat z následující části:

„---Hoch, zjehožživota jsem tuto vypravoval nepatrnou episodku, byl nejlepšim, nejupřimnějším mým prítelem.

Znali jsme se od nejútlejšího mládí. Žili jsme pospolu, myslili a pracovali podle sebe; ale nepochopili jsme se, ažv trudných, trpkých dobách neštěstí a utrpení.

Co následuje, vypravuju z části dle zápisků, z části dle ústniho vypravování přitelova. Neměním, nezatajuju, neokrašluju ničeho, leda že nechávám prítele vypravovati nepretržitě, co mi byl vypravoval ze svého života v různých dobách fragmentárnè. "21

Celou citovanou část jistě nelze připsat předchozímu heterodiegetickému vypravěči. Kdo zde promlouvá, je vlastně autor předchozího textu, který předchozí text demaskuje jako své zápisky, ve kterých figuruje určitý vypravěčský typ. Na druhé straně tento autor není v žádném případě totožný $s$ autorem Jakubem Arbesem; jedná se o rétorickou ich-formu s metanarativním komentářem, jinými slovy jsme zde svědky jakýchsi do sebe vnořených narativních rámců, což pro Arbesova romaneta není ničím výjimečným. Po celé této části následuje vyprávění vlastního př́běhu, který ovšem vypráví vypravěčův přítel. V textu se tak objevuje nový vypravěč, tentokrát homodiegetický. $V$ průběhu jeho vyprávění některé části př́běhu, jež mu nejsou známy, přebírá ženská protagonistka Ismena. Jedná se o poměrně komplikovanou strukturu narativních promluv a vrstev, které se nejen střídají, ale rovněž představují různé na sobě závislé roviny. Je třeba se rozhodnout, jak takovou situaci řešit. Zde nemůže nastoupit strojové čtení, ale je nezbytný právě interpretační přistup, jenž jednotlivé části smysluplně segmentuje. Takový přístup musí brát v potaz nejen celek daného textu, ale de facto celé autorovo dílo. Konkrétně to znamená chápat celý tento úvodní segment romaneta jako zvláštní typ tzv. textu v textu, jenž není typem vloženého vyprávění, který má formální rysy zápisníku, deníku, čímž se liší od jiných projevů vyprávění u Arbesa, jehož nositeli jsou konkrétní postavy vyprávějící vložený příběh obvykle za účelem objasnit neznámé části př́běhu.

Další otázkou je, jak vymezit deskriptivní segmenty. Někdy se jedná o poměrně zjevné části popisu objektu, věci či postavy, jindy dochází ke konfúzi deskripce s narací, jako třebas v tomto případě: „V patách za hochem vystoupila z domku asi padesátiletá, prostě, ale čistě po domácku oblečená černovlasá žena, vjejižztváríi jevily se dosud stopy dř́vějš́s sličnosti." $22 \mathrm{~V}$ této větě se prostupuje narativní složka vztahující se k dějovosti a deskripce, která odkazuje k ženině popisu. Takovéto př́pady, které ukazují na to, jak jsou obě složky funkčně propojeny, nelze řešit čistě formálně. Delimitace deskriptivních částí je proto prováděna u zjevných 
segmentů textu, jako je tomu i v následující ukázce, kde podtržená část je zrovna takovým deskriptivním segmentem:

„Nesa v pravici pár čistè vyleštěných vysokých bot vyběhl z domku jako laňka a v několika skocích octnul se na silnici, kde se na chvili zastavil, jakoby se rozmýšlel, kterou cestou se dáti.

Byl bez čepice a bez kabátu; toliko čistě vypraná košile a záplatované letní kalhoty z pytloviny, jejichžjedna nohavice byla až nad koleno vykasaná, kryly svalovité, pěkněrostlésnědé jeho tělo. Široképlece a mocněvyklenutá prsa svědčily o neobyčejnésile.

Výraz kulaté plné tváre s tupým nosem a jiskrným tmavým okem byl by býval vážný, ba prísný, kdyby ho nebyl mírnil kudrnatý černývlas, dodávajicítvári rázu poněkud šelmovského."23

Na jiných místech narativita a deskriptivita ovšem významně fúzují do té míry, že je poměrně komplikované je rigidně delimitovat, jako je tomu i v tomto prípadě:

„Šerým průjezdem dostali jsme se k několika schůdkům, vedoucím k malé zahrádce, založené na urovnaném svahu vršiny a nalézajicí se v stejné výši s prvním patrem domu.

Vystoupivše po schůdkách octli jsme se v zahrádce. Bylo v ní jen několik stromků a keřư jen několik záhonkủ a v pozadí malá, stinná besídka.

Pouhé to zákoutí, na jakéž snad jen Malá strana tak přebohata, a o nichž kromě několika osob nemívá obyčejně téměr nikdo ani tušení.

Vystupuje prvnípo schůdkách spatřil jsem mihnouti se zahrádkou štíhlou postavu ženskou v lehkém bledě šedivém šatě letním.

Mihnuvši se na několik kroků prede mnou zmizela otevřenými dveřmi v šeru prostranného pokoje, aniž by nás byla shledla.

Spatřil jsemjijen na okamžik; ale dojem, jaký na mne učinila, byl prekvapujicí.

Miloučká něžná tvár a bohatý plavý vlas zaleskly sev klamivých paprscích slunce, lehký krokzarupal v pisku a ztepilá postava, sotva se byla objevila, zmizela, zůstavivši po sobě jen poetické kouzlo, jakým ji byla obraznost má v okamžiku tom obestřela." ${ }^{24}$

Zde je potřeba rozhodnout v souvislosti s nastavenou interpretací, což v tomto př́padě znamená, že jako deskriptivní segment je vyznačena podtržená část. Za svého druhu deskripci lze ovšem docela dobře pokládat celou ukázku, anebo snad lépe hovořit o fúzování mezi narativním a deskriptivním potenciálem textu. I z tohoto důvodu se jeví jako nejpřijatelnější delimitovat pouze typologicky jednoznačně deskriptivní části textu.

Kazuistika ukazuje, jak komplikované a vlastně nejednoznačné je řešení nejen narativních promluv, ale i dalších segmentů v uměleckém narativu za účelem jejich formální taxonomizace. Uvedené př́klady jsou však důležité 
538 pro demonstraci způsobu, jakou cestou ke kvantitativním výsledkům docházím. Současně jsem si vědom řady úskalí, která takový přístup v sobě zahrnuje. ${ }^{25}$

Jsem-li schopen alespoň relativně, když ne zcela rigidně segmentovat text na jednotlivé části, mohu je nyní označit tagy, se kterými následně bude pracovat k tomu vytvořený program, který provede automatickou kvantifikaci. Otázka tagování představuje další část problému, který spočivá jednak v rozsahu tagované části a jednak je dán otázkou, zda některé textové segmenty nemohou být součástí jiných segmentů. To je př́klad deskripce. Otázka totiž zní: má být deskripce chápána izolovaně od segmentu vypravěče, aneboji pod tento subsumovat? Deskripce sice není narací, avšak uvedená strategie počíá s tím, že je součástí segmentu daného typu vypravěče jakožto jeho nenarativní složka. Ačkoli deskripci vymezuji konkrétními tagy, začleňuji ji do př́slušného rámce vypravěče, nebot' jeho aktivitu chápu nejen v souvislosti s vyprávěním příběhu, ale též s budováním fikčního světa, na kterém se způsob a míra deskripce samozřejmě zásadně podílí. Možný je však i opačný př́stup, kdy deskripce bude vyčleněna samostatně. (V každém př́padě je možné z př́slušných grafü, které zde prezentuji, prostým odečtením podílu deskripce od narativního segmentu získat podíl „„čistě“ narativní části.) Poslední ukázka ostatně prokazuje, že obě složky spolu funkčně souvisí. Struktura tagovaných segmentů potom vypadá následovně:26

\section{VN_X $\mathbf{X}^{27}$}

Dívka naslouchá napnutě. Ale i tyto zvuky dozněly - i v Loretě odbila desátá a nastalo opět jen šumem potoka rušené hluboké ticho noční.

Dívka jako ve snu odvrací se od okna.

\section{$\mathbf{X}$}

Tvář její jest opět rozpálena, oko rozjiskřeno, jakoby jí byla znova divoká vášeň duši rozechvěla. Cosi zvláštního, neobyčejného děje se v duši té, zmítané trpkými, bolestnými vzpomínkami. $V$ celém vzezření jeví se prudké pobouření, náruživé rozjitření, jaké obyčejně předcházívá skutek rozhodný, ba zoufalý.

$\mathbf{Y}$

\section{VN_Y}

V případě promluvy postav je tato vyčleněna zvlášt', tj. mimo část příslušného vypravěče, takže tvoří samostatný segment, kdy mezi částí vypravěče a promluvy postavy je vztah disjunkce; platí tedy, že segment je bud'to součástí promluvy vypravěče nebo postavy. Poněkud jiná je ovšem situace tehdy, jedná-li

25 Problémem může být zejména jistá míra introspekce. Na straně druhé se však nejedná o ryze subjektivní a náhodný postup, ale o takový, který vyplývá z přijatých naratologických premis. Jak uvidíme na konkrétních grafech, tyto premisy respektují Genettovu taxonomii narativních promluv, která se zakládá na přítomnosti/nepř́itomnosti vypravěče v př́iběhu, cožje typ tzv. homodiegetického a heterodiegetického vypravěče, a na přítomnosti/nepřítomnosti rámujícího vyprávění, což je př́ípad tzv. intradiegetického a extradiegetického vypravění. Jak upozornila S. Rimmon-Kenanová, oba typy se mohou dále kombinovat, což však v této práci nereflektuji.

$26 \mathrm{~V}$ př́padě deskripce jsem již uvedl, že tuto subsumuji pod př́slušný vypravěčský typ (v této ukázce je deskripce součástí heterodiegetického segmentu).

27 Tagset viz níže. 
se o vložené vyprávění neboli o tzv. intradiegetický typ. I zde sice platí, že celý $\mathbf{5 3 9}$ takový segment intradiegetické narace je rámován instančně vyšší narativní rovinou, avšak na úrovni jeho tagování postupujeme stejně jako v př́padě delimitace prímé řeči, tzn. tagujeme jej samostatně. Jak ukážu na konkrétních př́kladech, u Arbesa dochází dokonce $\mathrm{k}$ víceúrovňovému narativnímu zapuštění.

Jak lze vidět na předchozím př́kladu, zavedli jsme pro delimitaci textových částí sadu speciálních tagů, které prozatím pokrývají ty ze segmentů, které vyčleňujeme. V Tabulce 1 je jejich prozatímní soupis s tím, že počet tagů se samozřejmě může rozrůstat tak, jak si to bude vyžadovat samotný materiál.

\begin{tabular}{|c|c|}
\hline $\mathrm{x}$ & začátek deskripce \\
\hline $\mathrm{Y}$ & konec deskripce \\
\hline $\mathrm{P}$ & začátek př́mé řeči \\
\hline $\mathrm{R}$ & konec přímé řeči \\
\hline VM_X & vnitřní monolog (začátek) - polopřímá řeč \\
\hline VM_Y & vnitřní monolog (konec) - polopřímá řeč \\
\hline CM_X & citovaný monolog (začátek) \\
\hline CM_Y & citovaný monolog (konec) \\
\hline VN_X & vypravěč neosobní (začátek) - heterodiegetický \\
\hline VN_Y & vypravěč neosobní (konec) - heterodiegetický \\
\hline VO_X & vypravěč osobní (začátek) - homodiegetický \\
\hline VO_Y & vypravěč osobní (konec) - homodiegetický \\
\hline V1_X & vložené vyprávění 1. instance (začátek) - intradiegetický \\
\hline V1_Y & vložené vyprávění 1. instance (konec) - intradiegetický \\
\hline P_1 & začátek přímé řeči ve vloženém vyprávění 1 . instance \\
\hline R_1 & konec př́mé řeči ve vloženém vyprávění 1. instance \\
\hline $\mathrm{V} 2 \_\mathrm{X}$ & vložené vyprávění 2. instance (začátek) - intradiegetický \\
\hline V2_Y & vložené vyprávění 2. instance (konec) - intradiegetický \\
\hline P_2 & začátek př́mé řeči ve vloženém vyprávění 2. instance \\
\hline R_2 & konec př́mé řeči ve vloženém vyprávění 2 . instance \\
\hline $\mathrm{V}_{3} \mathrm{X}$ & vložené vyprávění 3. instance (začátek) - intradiegetický \\
\hline $\mathrm{V}_{3} \mathrm{Y}$ & vložené vyprávění 3. instance (konec) - intradiegetický \\
\hline P_3 & začátek přímé řeči ve vloženém vyprávění 1 . instance \\
\hline R_3 & konec prímé řeči ve vloženém vyprávění 1. instance \\
\hline $\mathrm{R} \_\mathrm{X}$ & rétorický vypravěč (začátek) \\
\hline R_Y & rétorický vypravěč (konec) \\
\hline D_X & začátek vloženého textu (dopis, rkp., noviny, zápisník, apod.) \\
\hline D_Y & konec vloženého textu (dopis, rkp., noviny, zápisník, apod.) \\
\hline S_X & začátek snového segmentu \\
\hline S_Y & konec snového segmentu \\
\hline DVN_X & začátek pásma heterodiegetického vypravěče ve vloženém textu \\
\hline DVN_Y & konec pásma heterodiegetického vypravěče ve vloženém textu \\
\hline
\end{tabular}




\begin{tabular}{|c|c|c|}
\hline 540 & DR_X & začátek rétorického vyprávění ve vloženém textu \\
\hline & DR_Y & konec rétorického vyprávění ve vloženém textu \\
\hline & DP & začátek přímé řeči ve vloženém textu \\
\hline & DR & konec př́mé řeči ve vloženém textu \\
\hline & $\mathrm{DX}$ & začátek deskripce ve vloženém textu \\
\hline & DY & konec deskripce ve vloženém textu \\
\hline
\end{tabular}

Tabulka 1: Tagset pro delimitaci segmentů fikčních narativů

Volba konkrétních tagů je samozřejmě záležitostí pracovního nastavení, žádná předepsaná norma zde neexistuje. $\mathrm{V}$ tomto př́padě jsem tagy volil tak, aby v programu mohly být definovány jako jeden znak, respektive jako jedna indexovatelná hodnota. Proto bylo nezbytné, aby byl tag komplexním znakem bez mezer. Tím se dostávám $\mathrm{k}$ vlastnímu strojovému zpracování takto připraveného textu. Za tímto účelem jsem vypracoval script v jazyce Python, jehož část kódu zde pro názornost přetiskuji:

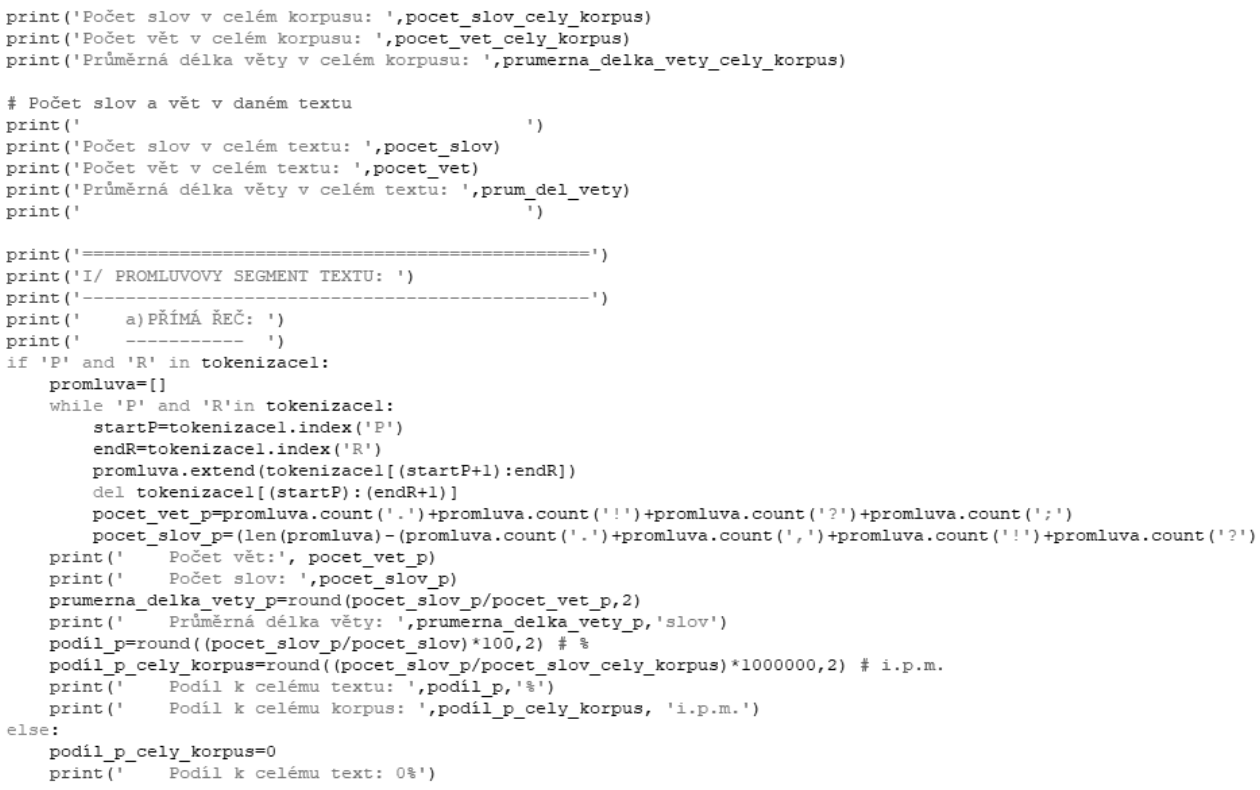

Obr. 6: Výpis z programu Python na strojovou kvantifikaci segmentů fikčního narativu

Program je v této fázi schopen spočítat slova, věty a průměrnou délku věty jak na úrovni celého korpusu, konkrétních textů, tak v rámci jeho dílčích segmentů (na obrázku se jedná o př́mou řeč), jež jsou (na základě počtu slov) vztaženy k celému textu (procentuální složka) a korpusu (hodnota relativní četnosti v instances per milionem), čímž je možná komparace jednotlivých segmentů mezi texty nestejné velikosti, respektive délky. Na výstupu program generuje tabulku hodnot, jejíž ukázkový výpis je na obr. 7, spolu s grafem. 


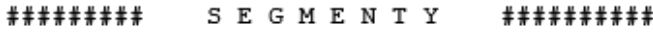

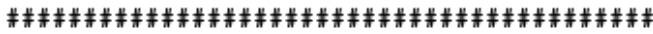

Zadej jméno otagovaného souboru, nebo ukonči program klávesou q: Ďábel na skřipci

Počet slov v celém korpusu: 103490

Počet vět $\mathrm{v}$ celém korpusu: 6430

Průměrná délka věty $\mathrm{v}$ celém korpusu: 16.09

Počet slov v celém textu: 10342

Počet vět $v$ celém textu: 815

Průměrná délka věty $\mathrm{v}$ celém textu: 12.69

I/ PROMLUVOVY SEGMENT TEXTU:

a) PŘíMÁ ŘEČ:

Počet vět: 329

Počet slov: 3562

Průměrná délka věty: 10.83 slov

Podíl k celému textu: 34.44 웅

Podíl k celému korpus: 34418.78 i.p.m.

b) CITOVANÝ MONOLOG:

Podíl k celému text: 0 응

c) POLOPŘÍMÁ ŘEE :

Podíl $\mathrm{k}$ celému text: 0 웅

II/ NARATIVNÍ SEGMENT TEXTU:

a) HOMODIEGETICKÝ VYPRAVĚČ:

Počet vět: 464

Počet slov: 6390

Průměrná délka věty: 13.77 slov

Podíl k celému textu: 61.79 웅

Podíl k celému korpus: 61745.1 i.p.m.

Obr. 7: Ukázka výstupových hodnot programu prvního Arbesova romaneta Ďábel na skřipci 


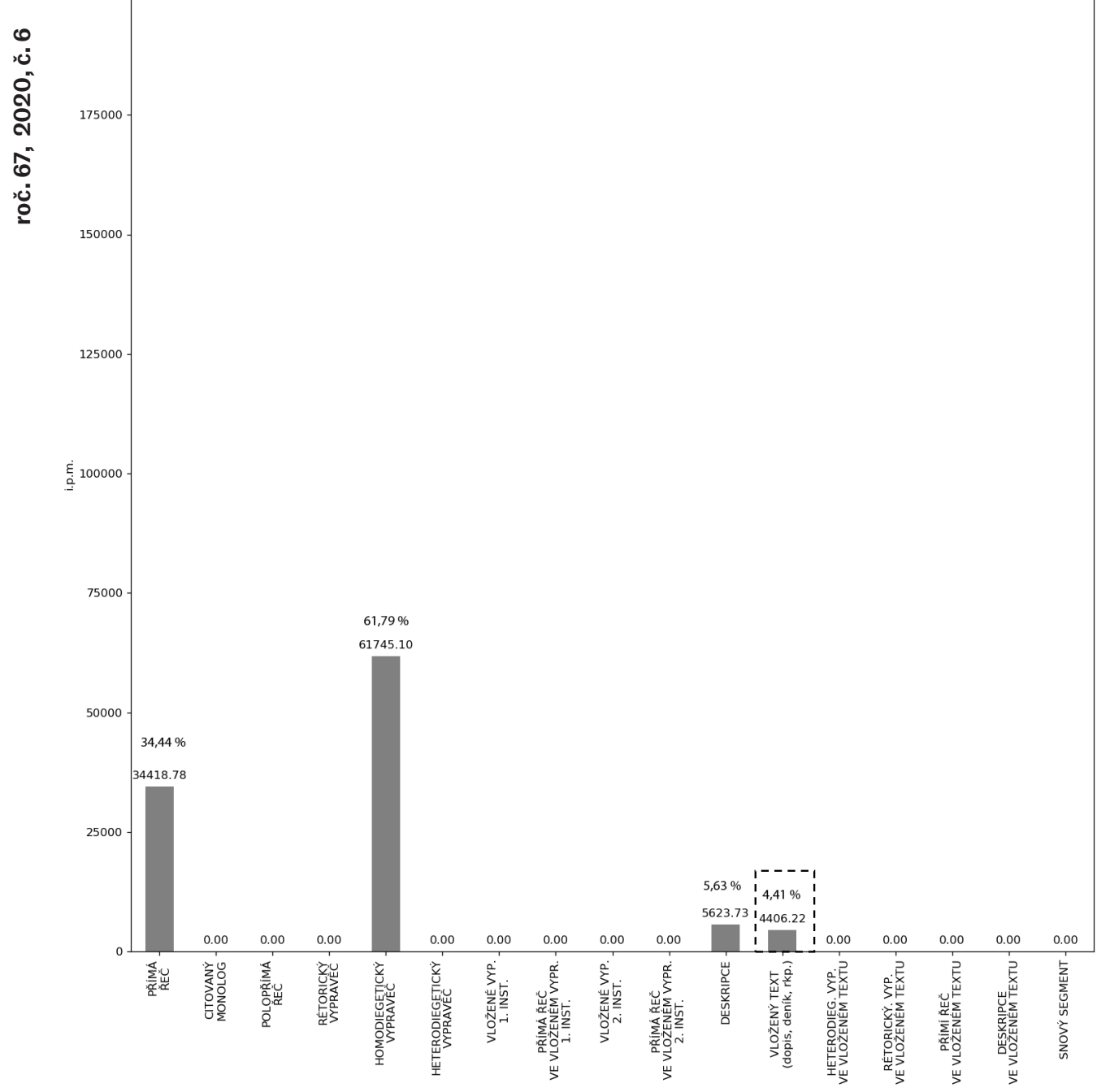

Graf 2: Četnosti textových segmentů v romanetu Ďábel na skřipci v i.p.m. vyjadřující poměr k celému korpusu a v procentech, která vyjadřují poměr $\mathrm{k}$ danému textu (výstup z programu Python) 


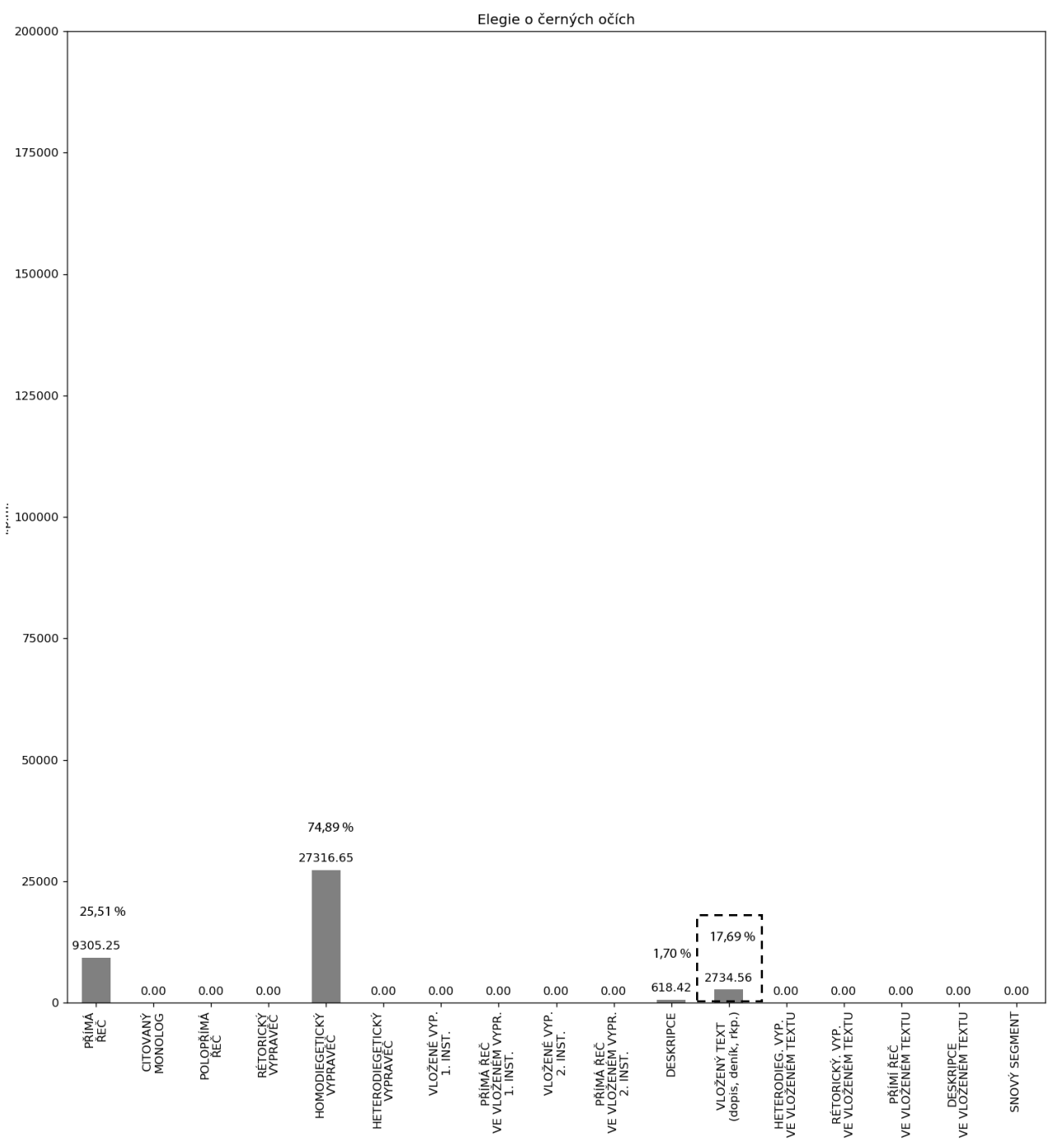

Graf: 3: Četnosti textových segmentů v romanetu Elegie o černých očích vi.p.m. vyjadřující poměr k celému korpusu a v procentech, která vyjadřují poměr k danému textu (výstup z programu Python) 


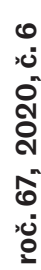

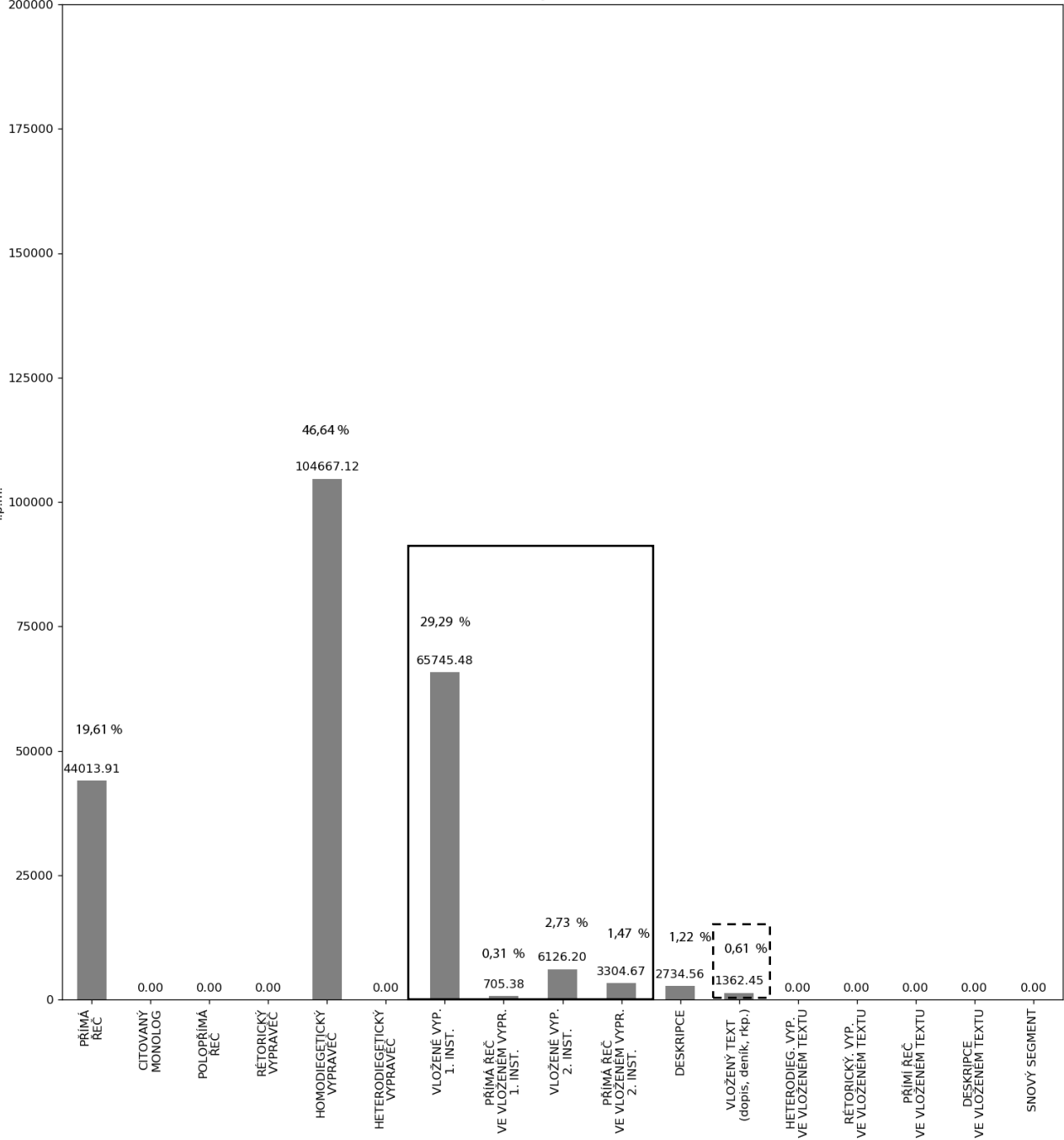

Graf 4: Četnosti textových segmentů v romanetu Svatý Xaverius v i.p.m. vyjadřující poměr k celému korpusu a v procentech, která vyjadřují poměr $\mathrm{k}$ danému textu (výstup z programu Python) 


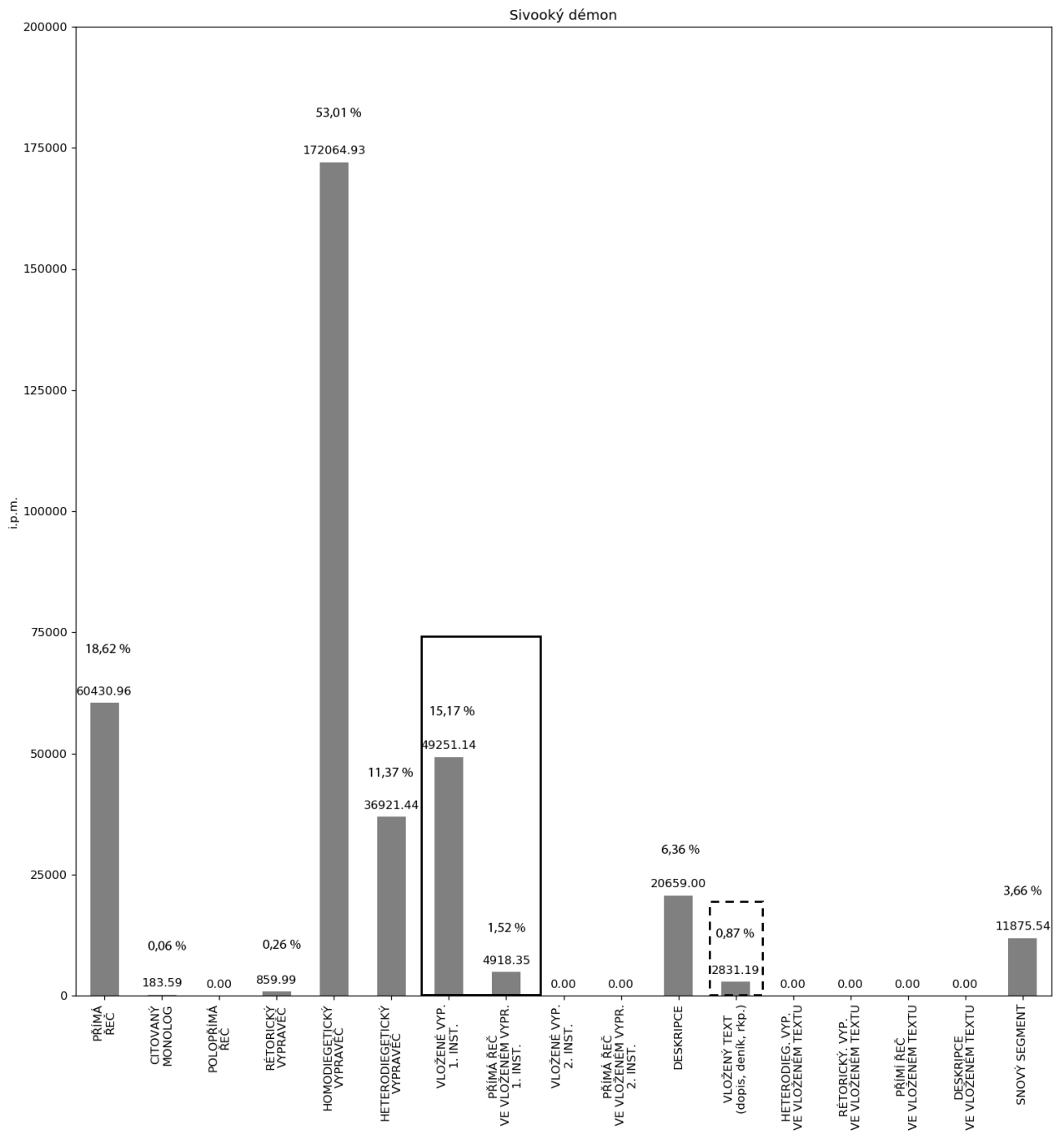

Graf 5: Četnosti textových segmentů v romanetu Sivooký démon v i.p.m. vyjadřující poměr k celému korpusu a v procentech, která vyjadřují poměr k danému textu (výstup z programu Python) 


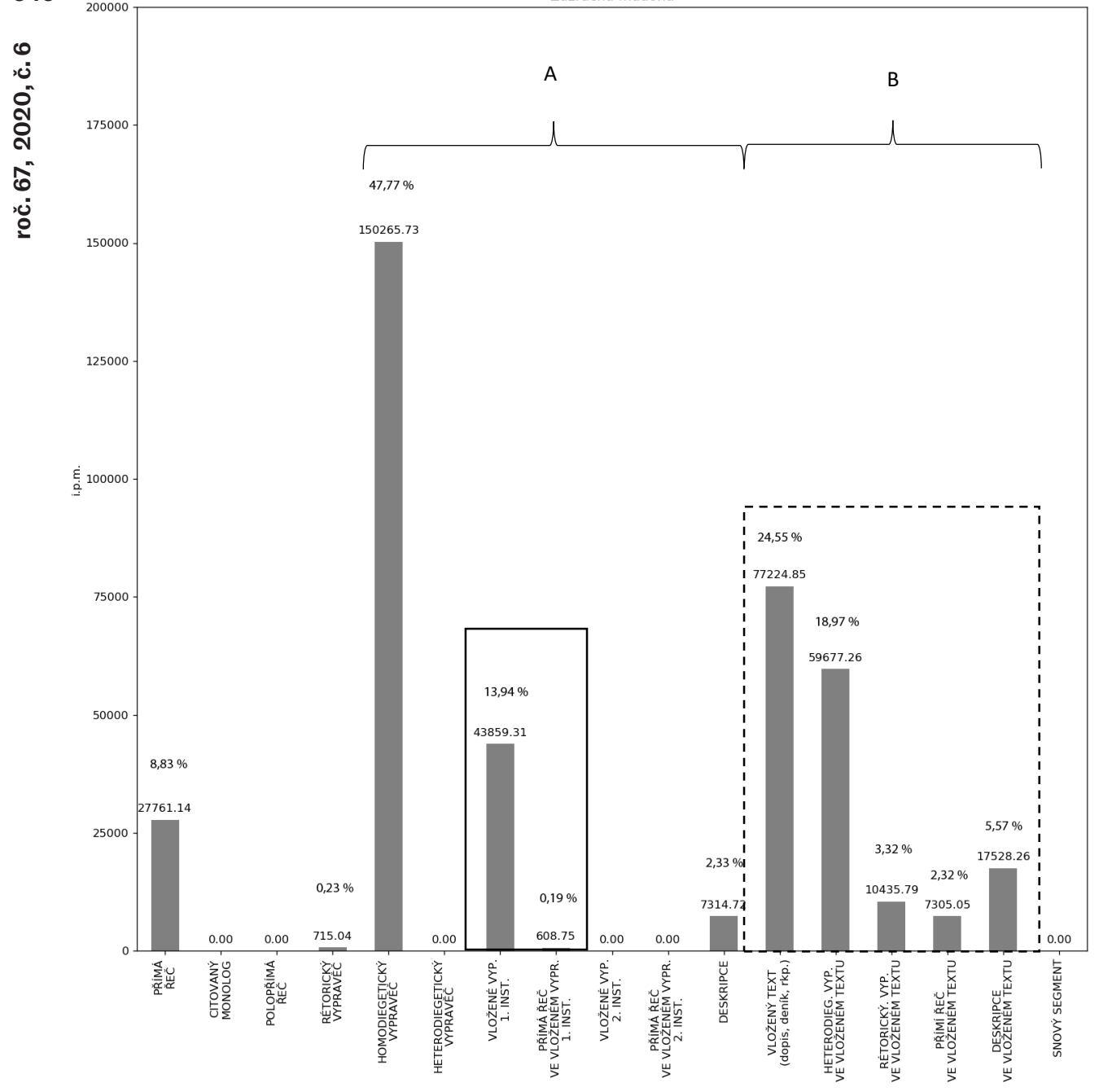

Graf 6: Četnosti textových segmentů v romanetu Zázračná madona v i.p.m. vyjadřující poměr k celému korpusu a v procentech, která vyjadřují poměr k danému textu (výstup z programu Python) 
Jelikož zde pracuji s velmi omezeným vzorkem dat, nelze prozatím k nějaké finální interpretaci přistoupit. O tu však v tuto chvíli nejde, nebot jak jsem již uvedl, mým záměrem není představit hotový projektový výstup, ale metodologickou prezentaci a její kritickou reflexi. Proto i následný výklad je třeba chápat jako způsob, jakým se interpretace může vydat, nikoli jako její definitivní a konečný závěr. Je možné, a dokonce nemálo pravděpodobné, že po finálním zpracování korpusu (nejen) Arbesových próz se řada věcí bude jevit v jiném světle, nicméně princip výkladu zůstává stejný.

Na prostorových modelech lze sledovat následující: U prvních dvou modelů (Ďábel na skřipci a Svatý Xaverius) je topografické schéma výrazně binární, tvoří jej dvě kontrastní oblasti, z nichž jedna je centrální a náleží v obou případech do středu Malé Strany, druhá se nachází za jejími hranicemi. Tato polarita určuje základní prostorové paradigma, ve kterém hraje důležitou roli rovněž hranice, která je v historické topografii definována hranicemi Malé Strany. Zde si lze povšimnout korelace mezi fikční topografií a historickou topografií; po celé 19. století byla Praha obehnána prstencem městských hradeb, teprve až koncem století se tento původně ještě středověký půdorys města začal proměňovat v souvislosti s jeho modernizací. ${ }^{28}$ Na uvedených modelech lze sledovat, jak tento historický fakt ovlivňuje fikční topografii. Přitom se zde nejedná o jeho prosté přenesení do světa literární fikce, ale o specifickou strukturně-ontologickou transformaci, ${ }^{29}$ jejímž výsledkem je v tomto případě model konfrontující vnitřní a vnější prostor, ve kterém sehrává důležitou funkci hranice. Ta je sice ve světě jmenovaných Arbesových romanet topograficky lokalizována do jedné z malostranských bran (v případě Dábla na skřipci se jedná o Strahovskou bránu, v romanetu Svatý Xaverius o bránu Újezdskou), avšak pojem hranice má v obou fikčních světech širší význam, který se zdaleka neomezuje jen na topografii. Vztah mezi vnitřním a vnějším prostorem se zde realizuje rovněž jako vztah mezi vědomím a racionalitou na straně jedné a snovým (místy až halucinačním) a iracionálním na straně druhé. Překročením této hranice, jako je tomu zejména ve Svatém Xaveriovi, dochází ke kulminaci dějové zápletky. Ve Svatém Xaveriovi se vypravěč a protagonista po delším pátrání vydávají vyzvednout domnělý poklad, který se podle výpočtů má nalézat za hranicemi města v opuštěné části Smíchova (viz obr. 2). Jeho zdánlivé vyzvednutí, jež je ve skutečnosti důsledkem smyslového klamu a vypjatého vzrušení, má pro protagonistu de facto osudové následky.

V čem se však oba modely přece jenom odlišují, je důraz na centralitu vnitřního prostoru, jak to vidíme ve Svatém Xaveriovi. Centralita je zde vytvářena několika prostorovými pásmy, z nichž vnější okruh tvoří prstenec malostranských hradeb, vnitřní potom centrum Malé Strany, a zejména svatomikulášský chrám. V něm totiž protagonista př́běhu nachází obraz svatého Xaveria, který interpretuje jako skrytou mapu vedoucí k pokladu. Samotné místo kostela se mu jeví jako pomyslný střed polygonálního prostoru tvořeného půdorysem Malé Strany, odkud vypočítává směr a cíl místa s pokladem. Je zde tak dvojí základní prostorové

28 Srov. JANÁČEK, Josef: Malé dějiny Prahy. Praha : Panorama, 1983, s. 278 - 280.

29 Srov. RONENOVÁ, Ruth: Možné světy v teorii literatury. Přel. Miroslav Červenka. Brno: Host, 2006, s. 21. 
paradigma, které je tvořeno jednak horizontálními vztahy mezi centrální a periferní lokací děje, jednak horizontálními vztahy určenými tematizovanou centralitou vnitřního prostoru města. Uvedené prostorové paradigma se však zdaleka netýká výhradně topografie; ta je totiž jakýmsi průmětem vnitřního nastavení postav a současně funkčně koreluje s narativní kompozicí. Výsledkem takové strukturace je jedinečná evokace mysteriózní Prahy. Další modely (viz obr. 3 a 4) ukazují, jak se toto binární prostorové paradigma postupně rozpadá a je nahrazováno jiným paradigmatem, jehož ústředním rysem se stává motiv cesty. Jestliže ještě v Sivookém démonovi můžeme sledovat rezidua centrálního prostorového rámce, kterým je zde Střelecký ostrov s přilehlou oblastí Kampy, potom v Zázračné madoně taková centrální lokace již chybí. Ústředním dějištěm se stává malostranská periferie Nového Světa s tím, že pražský dějový rámec je mnohem širší, nebot' zasahuje i oblasti Starého Města. Co je zde však dominantním jevem, je cesta, která celý prostor proměňuje v labyrint. ${ }^{30}$

Na rozdíl od Nerudových Povídek malostranských nesituuje Arbes dějiště svých próz výhradně do topografického rámce Malé Strany (viz obr. 5), ale významně jej překračuje, at již směrem do jiných městských částí (graf 1 ukazuje, že nejčastějšími lokacemi ve vybraných romanetech jsou Újezd, Smíchov a Malá Strana), anebo zcela mimo hlavní město, jako je tomu v Zázračné madoně, kde se část př́běhu odehrává na Šumavě. To však nic nemění na skutečnosti, že zde platí základní prostorové schéma, o kterém jsme mluvili. Venkov je oním vnějším prostorem, který na rozdíl od Svatého Xaveria disponuje rozvinutými významy centrality a vertikality. Tím, co jsem až doposud konstatoval, nehodlám tvrdit, že základní významy, jakými jsou polarita mezi vnějším a vnitřním prostorem, prostorová vertikalita či prostor jako labyrint, nejsou obsaženy ve všech zde jmenovaných prózách. Avšak rozdíl, na který dobře upozorňují právě prostorové modely, spočívá v tom, že v konkrétních prózách se realizuje jiná dominantní prostorová konfigurace.

Jak ovšem s uvedeným souvisí druhá část týkající se kvantifikace segmentů textu? Předně je třeba říci, že se jedná o další oblast strukturace fikčního textu a že jako takovou ji lze zkoumat jak samostatně, tak ve vztahu kjiným strukturním rovinám textu a sledovat, zda tu nedochází ke strukturním relacím, jež by bylo možné popsat a př́padně zobecnit. Porovnám-li z tohoto úhlu pohledu první dvě, respektive tři Arbesova romaneta, potom vidím, že zde situace není zcela analogická. Analogii v prrípadě kvantitativních modelů můžeme konstatovat mezi romanety Ďábel na skřipci a Elegie o černých očích (graf 2 a 3), zatímco v př́padě prostorových modelů jsme analogii konstatovali mezi Ďáblem na skripci a Svatým Xaveriem. $\mathrm{Z}$ hlediska kvantitativních modelů je však situace jiná. Svatý Xaverius na rozdíl od předchozích dvou romanet disponuje odlišnou stratifikací segmentů, což je způsobeno př́tomností vloženého (intradiegetického) vyprávění, které je dokonce dvouinstanční, což znamená, že je zde jedno vložené vyprávění součástí jiného. Tento princip vložených narací se následně stupňuje, respektive modifikuje, jak dokládá situace v Zázračné madoně (viz graf 6). Zde je třeba říci, že segment,

30 Prostorové modely následujících Arbesových próz (Ukřižovaná, Newtonův mozek a Akrobati) vychází $\mathrm{z}$ těchto dvou základních paradigmat, které různě variují. Například v Newtonově mozku je vnější lokace, která náleží do oblasti Kinského zámečku (tedy opět za historickou hranicí Malé Strany), úzce spojena se snovým či halucinačním prožitkem, čímž se rovněž aktivuje horizontální prostorový význam. 
který jsme označili jako tzv. text v textu a kterým vyznačujeme pasáže, jež náleží $\mathbf{5 4 9}$ korespondenci, deníkům apod., mohou (avšak nutně nemusí) být svého druhu rovněž vloženým vyprávěním. ${ }^{31}$ Tyto se nalézají již v prvních dvou romanetech, avšak teprve v následujících prózách je tato narativní kompozice plně rozvinuta do té míry, že dochází bud'to k zanořování vyprávění do již vloženého vyprávění (viz Svatý Xaverius) anebo, jako je tomu v případě Zázračné madony, ke složitější kompozici, kdy se vedle sebe objevuje dvojí narativní rámec, z nichž první odpovídá vnitřně strukturovanému vloženému textu (B), druhý homodiegetickému vyprávění (A), jež samo dále obsahuje vložené vyprávění. Vidíme tedy, že narativní kompozice se postupně komplikuje a že jejím základem jsou vnořená vyprávění vycházející ze segmentu námi označeného jako text v textu.

S ohledem na prostorové modely lze celou tuto situaci chápat následovně: v romanetu Svatý Xaverius jsem konstatoval, že prostorový model je analogický k tomu, který platí pro romaneto Ďábel na skřipci. Avšak kvantitativní model Svatého Xaveria ukazuje, že situace je odlišná než v Ďáblu na skřipci. Systém vložených vyprávění narativní vrstvu výrazně člení, s čímž souvisí zvyšující se efekt prostorovosti. Prostorovost v literárním díle totiž není dána pouze topografií fikčního světa a způsobem jejího uspořádání, ale doslova se na ní podílí veškeré fikční entity a strukturní vrstvy, včetně narativní roviny. Systém vložených vyprávění spolu s prostorovým modelem Svatého Xaveria významně posiluje význam prostorové centrality a vertikality. Tato významotvorná funkce narativu vyplývající z intradiegetických segmentů se v dalších prózách, zejména však v Zázračné madoně, komplikuje. Nicméně prostorový model Zázračné madony je založen na jiném paradigmatu, jak jsme uvedli. Na druhé straně jsme rovněž konstatovali, že základní prostorové významy jsou ve zde sledovaných Arbesových romanetech př́tomny vždy, avšak v rámci odlišných konfigurací. A právě na komparaci obou typů modelů můžeme sledovat, jak se princip prostorově centrálního vertikálního modelu funkčně prostupuje s modelem horizontálním právě na základě kombinací různých úrovní strukturace literárního textu.

\section{Závěrem}

Je třeba znovu upozornit, že uvedené závěry jsou prozatímní, nebot jsou součástí komplexního projektu, který počítá s postupným zpracováním nejen veškeré Arbesovy prózy, ale i dalších literárních (a v konečném důsledku i neliterárních) textů 19. století tematizujících pražskou topografii. Tím, jak budou přibývat data a modely, může pochopitelně dojít k proměně či významné modifikaci výkladu. A to je ostatně jeden z podstatných rysů tohoto př́stupu, který se odvijí z povahy modelů, a nikoli z apriorních závěrů, ke kterým by tyto modely byly pouhou ilustrací. Na druhou stranu je třeba rovněž uvést, že žádný z modelů není samospasitelný a že nutně vyžaduje součinnost s analyzovaným textem, nebot' výsledky je třeba především interpretovat, nikoli pouze popisovat. Modely však přináší to, co by bez nich bylo jen složitě př́stupné, obzvláště budeme-li postupně operovat s narůstající materiálovou základnou. Jejich př́nosem je schopnost systematické analýzy založené na četných komparacích. Právě srovnávání mezi modely

31 To platí pro prózy Ďábel na skřipci, Elegie o černých očích a Sivookém démonu. V próze Zázračná madona se sice jedná o typ text $\mathrm{v}$ textu, avšak ve skutečnosti nejde o vložené vyprávění. 
550 odlišných strukturních oblastí textu otevírá nemalé možnosti pro experimentování v literárněvědné interpretaci. $Z$ hlediska komparací je možné sledovat nejen proměny $\mathrm{v}$ dané strukturní vrstvě, ale také mezi vrstvami navzájem. Zajímavé výsledky lze očekávat rovněž od srovnání mezi prostorovými modely fikčních topografií a mapami zachycujícími proměnu reálné historické topografie místa.

Tyto (a další cíle) jsou součástí projektu, který by měl ve výsledku směřovat $\mathrm{k}$ vytvoření rozsáhlejšího digitálního korpusu české prózy 19. století. ${ }^{32} \mathrm{Je}$ samozřejmé, že nebude možné veškerou prózu tohoto období analyzovat pomocí prostorových modelů. Ve skutečnosti půjde jen o část textů, které výrazně tematizují pražskou topografii. V součinnosti s narůstajícím materiálem bude rovněž důležité promýšlet a modifikovat návrh segmentace literárního textu. Cílem totiž není vměstnat literární materiál do předem připravených schémat, ale tyto navrhovat s ohledem na povahu materiálu.

\section{Pramene}

ARBES, Jakub: Romaneta. Výbor uspořádala Jaroslava Janáčková, edičně připravila Martina Sendlerová a komentáře napsaly Jaroslava Janáčková a Martina Sendlerová. Praha : Nakladatelství Lidové noviny, 2006.

ARBES, Jakub: Svatý Xaverius a jiná romaneta. Výbor uspořádal, k vydání připravil, ediční poznámkou a vysvětlivkami opatřil Josef Moravec, doslov napsal Karel Krejčí. Praha : Odeon, 1969.

NERUDA, Jan: Povidky malostranské. Praha : Státní pedagogické nakladatelství, 1966.

\section{Literatúra}

BACHMANN-MEDICK, Doris: Cultural Turns: Neuorientierungen in den Kulturwissenschaften. Reinbek bei Hamburg: Rowohlt Taschenbuch Verlag, 2007.

COOPER, David-DONALDSON, Christopher-MURRIETA-FLORES, Patricie: Literary Mapping in the Digital Age. London : Routledge, 2016.

ČECH, Radek - POPESCU, Ian-Iovitz - ALTMANN, Gabriel: Metody kvantitativníanalýzy (nejen) básnických textů. Olomouc: Univerzita Palackého v Olomouci, 2014.

DOLEŽEL, Lubomír: Narativní zpưsobyv české literatuře. Př́ibram: Pistorius \& Olšanská, 2014.

ENGBERG-PEDERSEN, Anders: Literature and Cartography: Theories, Histories, Genres. Cambridge - London : The MIT Press, 2017.

HERMAN, David: Quantitative Methods in Narratology: A Corpus-Based Study of Motion Events in Stories. In: JANIDIS, Fotis - PIER, John-SCHMID, Wolf-MEISTER, Jan Christoph (eds.): Narratology beyond Literary Criticism - Contributions to Narrative Theory. New York - Berlin : Walter de Gruyter, 2005, s. 125 - 150.

CHATMAN, Seymour: Dohodnuté terminy: rétorika narativu ve fikci a filmu. Přel. Brigita a Luboš Ptáčkovi. Olomouc : Univerzita Palackého v Olomouci, 2000.

JANÁČEK, Josef: Malé dějiny Prahy. Praha : Panorama, 1983.

MORETTI, Franco: Atlas of the European Novel, 1800 - 1900. New York - London : Verso, 1999. 
MORETTI, Franco: Grafy, mapy, stromy: Abstraktni modely literární historie. Přel. Olga Čaplyginová. Praha : Karolinum, 2014.

RIMMON-KENANOVÁ, Shlomith: Poetika vyprávění. Přel. Vanda Pickettová. Brno : Host, 2001.

RONENOVÁ, Ruth: Možné světy v teorii literatury. Přel. Miroslav Červenka. Brno: Host, 2006.

YEVSEYEV, Vyacheslav: Measuring Narrativity in Literary Texts. In: JANIDIS, Fotis-PIER, John-SCHMID, Wolf-MEISTER, Jan Christoph (eds.): Narratology beyond Literary Criticism - Contributions to Narrative Theory. New York - Berlin : Walter de Gruyter, 2005, s. $109-124$.

\section{Elektronické zdroje}

Cartographic Imaginaries: Interpreting Literary Atlas. Dostupné na: http://www.orieldavies.org/en/exhibition/cartographic-imaginaries-interpreting-literary-atlas-wales

PIATTI, Barbara: A Literary Atlas of Europe. Dostupné na: http://www. literaturatlas.eu/en/index.html

REUSCHEL, Anne-Kathrin: Modelling Uncertain Geodata for the Literary Atlas of Europe. Dostupné na: http://www.literaturatlas.eu/ files/2013/01/Reuschel_Modelling_uncertain_Geodata.pdf

Mgr. Richard Změlík, Ph.D.

Katedra bohemistiky

Filozofická fakulta Univerzity

Palackého v Olomouci

Křižkovského 10

77900 Olomouc

Česká republika

E-mail: richard.zmelik@upol.cz 